\title{
Evento de letramento no Ensino Fundamental: a escrita do artigo de opinião
}

\author{
Aline de Sousa Nascimento \\ Universidade Federal do Ceará
}

\begin{abstract}
Resumo
Docentes, mediante práticas de letramento, conduzem o alunado à reflexão, à organização de ideias, e a perceber finalidades na leitura e na escrita. Trabalhamos neste artigo com o conceito de evento de letramento conforme Street (2012) e Kleiman (1995) a partir da análise de artigos de opinião produzidos por discentes do nono ano. O presente trabalho contribui para o debate acerca do letramento escolar, mediante práticas de letramento (STREET, 2012), pois um dos objetivos do ensino de língua portuguesa é ampliar a capacidade de utilizar leitura e escrita do alunado, principalmente no Ensino Fundamental. Escolhemos o gênero discursivo artigo de opinião e justificamos o trabalho com este gênero a partir da leitura de Dolz e Schneuwly (2010), pois textos argumentativos precisam ser trabalhados também no Ensino Fundamental dentro da sala de aula. Acerca da argumentação, baseamo-nos em Fiorin (2015), Cavalcante (2015) e Gonzaga (2016).
\end{abstract}

Palavras-chave: Práticas de letramento; letramento escolar; artigo de opinião.

\begin{abstract}
Through literacy practices, teachers lead students to reflect, to organize ideas, and to perceive purposes in reading and writing. This paper deals with the concept of literacy event according to Street (2012) and Kleiman (1995) based on the analysis of opinion articles produced by ninth grade students. The present study contributes to the debate about literacy, through literacy practices (STREET, 2012), since one of the objectives of Portuguese language teaching is to increase the students' ability to use reading and writing, mainly in elementary school. We chose the discursive genre opinion article and justified the work with this genre within the classroom from the reading of Dolz and Schneuwly (2010), because argumentative texts need to be explored also in elementary school. With regard to argumentation, we use Fiorin (2015), Cavalcante (2015) and Gonzaga (2016).

Keywords: literacy practices; school literacy; opinion article.
\end{abstract}

\section{INTRODUÇÃO}

A educação básica regular é formada por crianças e adolescentes que estão em processo de evolução intelectual. Cada dia na escola, cada aula assistida e participada é uma gota a mais no oceano que é formado ao término da educação básica. Linguagem metafórica para melhor expressar o alunado antes e depois da educação básica. Educação básica que é dividida em Ensino Fundamental e Ensino Médio. O Ensino Fundamental é o alicerce de toda uma vida estudantil, o qual ecoará em todos os níveis de aprendizagem que o alunado tiver 
interesse ou acesso. E a escola, como instituição primeira nas práticas de letramento escolar, contribui de maneira fundamental nessa evolução intelectual. Como afirmam os Parâmetros Curriculares Nacionais (doravante PCNs):

Cabe à escola promover a sua ampliação de forma que, progressivamente, durante os oito anos do ensino fundamental, cada aluno se torne capaz de interpretar diferentes textos que circulam socialmente, de assumir a palavra e, como cidadão, de produzir textos eficazes nas mais variadas situações. (BRASIL, 1998, p.19)

Os PCNs da Língua Portuguesa para o Ensino Fundamental promovem o debate acerca da melhoria e da eficácia do ensino básico, que tem como um de seus objetivos: "considerar a necessidade de construir referências nacionais comuns ao processo educativo em todas as regiões brasileiras" (BRASIL, 1998). Defendem um ensino que traga ao alunado a compreensão dos usos da língua, que torne o alunado proficiente na escrita e na fala de língua materna nas diferentes situações comunicativas.

Tudo isso conversa com o conceito de Letramento proposto por Kleiman (2007) e Magalhães (2012). O conceito de letramento "refere-se à prática social da língua escrita, o que inclui os processos sociais da leitura e da escrita" (MAGALHÃES, 2012, p.19). Outra definição de letramento é "Podemos definir hoje o letramento como um conjunto de práticas sociais que usam a escrita, enquanto sistema simbólico e enquanto tecnologia, em contextos específicos, para objetivos específicos" (KLEIMAN, 1995, p. 19). Leitura e escrita não devem ser vistas como ações mecânicas, mas que estejam dentro de uma prática social; portanto, esse tornar-se proficiente na escrita é incentivado baseado em fatos relevantes para o alunado, já que o tema sobre o qual os alunos escreveram nos artigos analisados neste trabalho é um tópico conhecido da realidade social da maioria dos jovens da periferia. O tema é "Gravidez na adolescência: causas e consequências"1.

Objetivamos analisar os artigos de opinião produzidos por alunos e alunas do nono ano. Observar se, depois da uma intervenção através de uma sequência didática (DOLZ: NOVERRAZ \& SCHNEUWLY, 2010), houve avanço no processo da escrita. Saber se o aluno ou a aluna de nono ano diferenciou a tese do tema que foi proposto; se esse(a) discente desenvolveu uma tese (característica que não pode faltar em um texto argumentativo); se esse(a) aluno(a) usou vários tipos de argumento e quais os tipos que predominam na produção textual de discentes de nono ano. Verificamos se os textos produzidos aproximam-se do que

\footnotetext{
${ }^{1}$ Frase tema retirada do livro Língua portuguesa, $9^{\circ}$ ano. 3. ed. São Paulo, 2012. (Coleção Tecendo linguagens), de AMARAL, T. O. et al. O livro é adotado pela escola onde foi realizada a pesquisa.
} 
se espera de um artigo de opinião em sua estrutura, teor argumentativo, escolha de uma posição a partir do tema proposto e coerência da parte do autor ou autora.

Quando os docentes estimulam o letramento em sala de aula, objetivam formar alunos que sejam cidadãos, que reflitam sobre o que os cercam, estudantes cidadãos capazes de tomar uma posição crítica em diversos assuntos importantes para a sociedade, pois desde o início da vida escolar, o alunado deve ser estimulado a ler e a compreender, a ler e a interpretar, a ler e criticar, a ler e a se posicionar. Enfatizamos o verbo ler porque a leitura é um imprescindível recurso de letramento, que ajuda no desenvolvimento da capacidade de se expressar e ajuda na melhoria de produções escritas, portanto o letramento escolar é um tipo de letramento que refletirá na vida do aluno durante os anos de escola e também quando o aluno sair para a vida profissional.

Este trabalho é oriundo de minha dissertação de Mestrado intitulada "O Gênero discursivo artigo de opinião em práticas de letramento escolar", defendida em 2016 na Universidade Federal do Ceará.

\section{PRESSUPOSTOS TEÓRICOS}

É pertinente fazer uma diferenciação entre práticas de letramento e eventos de letramento. Evento de letramento refere-se às ações mais perceptíveis das atividades que envolvem a leitura e a escrita. Street (2012) traz a definição de Heath (1982, apud STREET, 2012), que caracteriza um "evento de letramento como qualquer ocasião em que um fragmento de escrita é integral à natureza das interações entre os participantes e de seus processos interpretativos". As práticas de letramento (termo criado por Street) distanciam-se do contexto imediato em que os eventos ocorrem, para situá-los e interpretá-los em contextos institucionais e culturais nos quais os participantes atribuem significados à escrita, à leitura e aos eventos de que participam. Como afirma o linguista britânico: "Por práticas de letramento vou me referir não só ao evento em si, mas a concepções do processo de leitura e escrita que as pessoas sustêm quando engajadas no evento" (STREET, 2014, p.147). Os eventos de letramento são concretos e podem ser observados. As práticas de letramento são conceituais.

O ensino de língua portuguesa precisa desenvolver a competência discursiva do alunado e as práticas de letramento devem estar integradas na busca desse objetivo maior que é o aprendizado. Street (2012, p. 76) discorre acerca dessas práticas: "O conceito de práticas de letramento é realmente uma tentativa de lidar com os eventos e com os padrões de atividades de letramento, mas para ligá-los a alguma coisa mais ampla de natureza cultural e 
social". Promover um evento de letramento dentro do ambiente escolar atende à busca dos docentes de formar um alunado que utilize a escrita e a leitura como uma prática social.

Uma opção coerente nessa busca da escrita, visando a um objetivo, é a produção do gênero discursivo artigo de opinião, pois esse gênero é um veículo importante de argumentação, refutação e de defesa de posição. Ele é ideal para uma leitura e escrita reflexivas e com objetivos tangíveis para um público de nono ano do Ensino Fundamental.

Definimos o artigo de opinião como um gênero discursivo que "apresenta exemplares de textos analíticos que expressam o raciocínio e o juízo de valores de uma determinada pessoa" (ALMEIDA, 2012, P.111). Outro conceito diz que "se trata de um gênero marcadamente argumentativo e expositivo" (ALMEIDA, 2012, P.117). Bräkling (2000) aponta outra definição para artigo de opinião: “trata-se de [...] um gênero de discurso em que se busca convencer o outro de uma ideia, influenciá-lo, transformar os seus valores por meio de um processo de argumentação a favor de uma determinada posição assumida pelo produtor e refutação de possíveis opiniões divergentes".

Os autores que falam sobre textos argumentativos, também falam de argumentos que compõem esse tipo de texto. De acordo com Fiorin (2015, p. 69), "argumentos são proposições destinadas a fazer admitir uma dada tese". Outra definição de argumento nos é dada por Gonzaga (2016, p. 166), quando a professora diz que as ideias, as quais são desdobradas dentro de um texto argumentativo, aquelas que são desenvolvidas de maneira coerente, elas se tornam os argumentos. Fiorin (2015, p. 176) ainda esclarece que "um argumento é uma razão a favor ou contra um determinado ponto de vista".

Sabemos que existe uma gama de tipos de argumento, como, por exemplo, os apontados por Fiorin (2015, p. 260-262): "argumentos de causalidade; argumento por definição; argumento por analogia; argumento de autoridade", etc. Cavalcante (2016, p.3) fala do "argumento por comparação". Gonzaga (2016, p.166) também contribui para apontar essa variedade dos tipos de argumento ao elencar alguns. A seguir os mais recorrentes:

- Argumento de raciocínio lógico: é aquele que instaura conexões de sentido lógicas, como razão/consequência, analogia/comparação, causa/efeito, contraste, contraargumentação, dedução, indução.

- Argumento de provas concretas: são dados, estatísticas, gráficos, exemplos, fatos reais, leis, percentuais retirados de pesquisas científicas ou de fontes confiáveis.

- Argumento de autoridade: é a citação de um especialista, de uma autoridade em determinada área (GONZAGA. 2016, p.166).

Neste trabalho, procuramos desenvolver etapas para a escrita e reescrita do artigo de opinião construído pelos discentes. Chamamos aqui de etapas o que seria uma espécie de 
sequência didática. O termo "Sequência didática" surgiu de Dolz, Noverraz e Schneuwly (2010, p.82) que a definem como "um conjunto de atividades escolares organizadas de maneira sistemática, em torno de um gênero textual oral ou escrito." A sequência ajuda o alunado na compreensão e apropriação da escrita do gênero, pois conforme os autores citados explanam: "sequências didáticas servem para dar acesso aos alunos a práticas de linguagem novas ou dificilmente domináveis" (DOLZ, NOVERRAZ \& SCHNEUWLY, 2010, p. 98).

\section{A METODOLOGIA DE UM EVENTO DE LETRAMENTO EM UMA SALA DE AULA REAL}

Existem poucas pesquisas que exploram textos argumentativos no Ensino Fundamental. Trabalhar com práticas de letramento em uma sala de nono ano e construir um evento de letramento, no qual o gênero discursivo artigo de opinião tenha sido produzido pelos discentes, mostra que o alunado do Ensino Fundamental é capaz de argumentar e defender sua tese e que essa capacidade de escrever textos argumentativos não deve ser somente abordada e desenvolvida no Ensino Médio.

Participaram 18 estudantes do nono ano de uma escola pública que trabalharam com a estrutura do gênero discursivo artigo de opinião. Após a preparação, a partir de etapas didaticamente delimitadas, os estudantes redigiram seu próprio artigo, em norma culta da língua, sobre o tema "Gravidez na adolescência: causas e consequências".

Os autores voluntários foram oriundos de turmas e turnos diferentes. Os estudantes participantes cederam seus textos por adesão espontânea. Foram analisadas as seguintes categorias no texto inicial e no texto final do alunado:

\section{a) Diferenciação entre tema e tese:}

Os discentes souberam diferenciar tema, que foi dado, da tese que precisa ser desenvolvida? Essa é uma diferença importante para a produção do artigo de opinião. O tema é fornecido a todos, a tese não. A criação dessa ideia central no texto demonstra originalidade e indício de autoria própria. Conforme Cavalcante (2015), "Não se pode confundir o tópico principal do texto com a tese. O tópico é o tema em torno do qual a redação há de se desenvolver".

\section{b) Desenvolvimento da tese:}

Os discentes desenvolveram a tese para defendê-la? Cavalcante (2015) aponta uma definição para tese que a presente pesquisa concorda. A linguista afirma: "Já a tese, ou ponto de vista central, é de cada um, assim como é de cada um a escolha dos dados que darão 
forramento a essa opinião, que deve ser defendida com eficácia." Buscamos saber se o discente desenvolveu a tese para percebermos se houve indícios de autoria nos artigos de opinião.

\section{c) Tipos de argumento:}

Quais tipos de argumentos foram utilizados? Os tipos de argumento serão analisados à luz de Fiorin (2015) que expõe os principais tipos de argumento na obra "Argumentação", de 2015, e de Gonzaga (2016). Fiorin (2015, p. 69) assim definiu argumento: "Um argumento são proposições destinadas a fazer admitir uma dada tese."

A atividade compreendeu diversas etapas para a escritura do primeiro e do texto final que nos permite apontar, na análise, quais os tipos de argumento mais encontrados nos textos dos discentes. Conceituaremos cada tipo achado.

\section{Os passos para a escrita}

Acreditamos que a proposta de escrita, dentro da sala de aula, não pode ser simplesmente "jogada". O docente deve trabalhar de maneira sistemática e planejada para que depois da preparação surja a produção textual do alunado. Como declara Kato (1987, p.85), ao discorrer sobre "visões processuais da escritura",

Há muito não se acredita mais que escrever seja uma simples questão de inspiração, que pode ser expressa pela fórmula mágica pensou-escreveu. Sabe-se hoje que até mesmo os produtos mais criativos envolvem uma fase de pré-escritura e também uma de pós-escritura (Kato,1987, p.85)

Nas etapas, há a presença da observação, da escuta, da leitura e da escrita por parte dos (as) discentes, porque, como afirma Soares (1998, p. 48), "letramento envolve dois fenômenos bastante diferentes, a leitura e a escrita". A primeira parte do trabalho foi realizada em seis aulas de 50 minutos cada, nos turnos da manhã e da tarde. As etapas iniciais consistiram nos seguintes passos:

a) A docente falou sobre os textos argumentativos em geral. Em seguida, lemos, analisamos e interpretamos a linguagem verbal e a não-verbal de uma charge com teor argumentativo, que o livro didático ${ }^{2}$ apresentou para o alunado. Logo após, foi explicada a estrutura do artigo de opinião e a definição de argumento. Solicitamos aos alunos, como tarefa de casa, a pesquisa em qualquer site da Internet sobre os tipos de argumento. Os alunos deveriam escolher quatro tipos e defini-los. A escolha foi pessoal, de cada aluno.

\footnotetext{
2 AMARAL, T. O. et al. Língua portuguesa, 9 ano. 3. ed. São Paulo: Ibep, 2012.
} 
b) Depois os alunos leram um artigo de opinião para se familiarizarem com o gênero discursivo examinado. $\mathrm{O}$ artigo lido se chama "Paz social", de Gilberto Dimenstein, e está publicado no próprio livro didático adotado pela escola.

c) $\mathrm{O}$ artigo foi analisado oralmente com o direcionamento dado pela docente para identificarem a tese e os tipos de argumento utilizados. Perguntas foram feitas, como por exemplo: "Qual a ideia central do texto? Como o autor defendeu essa ideia? No texto há algum dado de uma pesquisa, um dado estatístico? O autor citou o nome de alguém que seja autoridade no assunto que o artigo abordou?".

d) Após isso, os alunos do nono ano leram outros dois textos que constam no próprio livro didático. Os dois são reportagens que falam sobre a sexualidade na adolescência. A primeira reportagem foi "Fale de sexo com eles", retirada da revista IstoÉ e publicada no livro didático aqui adotado. A segunda reportagem foi "Falta sexo", de Rosely Sayão, publicada pela Folha de São Paulo e que também está contida no livro didático.

e) Os discentes produziram o seu próprio artigo de opinião com o tema "Gravidez na adolescência: causas e consequências".

f) Foram selecionados 18 artigos de opinião produzidos pelos discentes (8 alunos da manhã e 10 alunos da tarde) a partir da adesão voluntária.

Para promover a reescrita dos textos dos discentes, desenvolvemos a segunda parte do trabalho, que foi realizada em oito aulas de 50 minutos cada, nos turnos da manhã e da tarde, com o intuito de se tornar uma intervenção. Essa ação interventiva consistiu nas seguintes etapas:

a) Os alunos assistiram ao documentário "Meninas: gravidez na adolescência", de Sandra Werneck. Esse documentário traz como temática a gravidez na adolescência, o cotidiano dessas adolescentes, de seus namorados e de suas famílias e o drama da vida real dessas meninas- mães moradoras de favelas no Rio de Janeiro.

b) Depois os discentes leram um artigo A GRAVIDEZ NA ADOLESCÊNCIA ${ }^{4}$ de, Giorgia Lay-Ang, e uma entrevista feita pelo doutor Dráuzio Varella com uma médica especialista em gravidez na adolescência ${ }^{5}$. Esses textos serviram como textos motivadores para dar suporte ao alunado na construção da argumentação.

\footnotetext{
3 "Meninas: gravidez na adolescência" é um documentário de 2006. Foi dirigido e produzido por Sandra Werneck.

4 LAY-ANG, Giorgia. "A Gravidez na Adolescência"; site: Brasil Escola. Disponível em $<$ http://brasilescola.uol.com.br/biologia/gravidez-adolescencia.htm>. Acesso em 10 de setembro de 2016.

${ }^{5}$ Publicado em 05/10/2011. Revisado em 18/10/2011. http://drauziovarella.com.br/mulher-2/gravidez-naadolescencia-2/. Acesso em 10 de setembro de 2016.
} 
c) Houve uma revisão sobre a estrutura do gênero argumentativo artigo de opinião e sobre os tipos de argumento. A revisão justifica-se para uma retomada de conteúdo que constrói uma ligação com o novo da aula do dia.

d) Os alunos leram ainda outro texto argumentativo, um artigo de opinião ${ }^{6}$, de Gilmaci Santos, que é deputado estadual e presidente estadual do PRB de São Paulo. O título é "Gravidez na adolescência: grave problema social".

e) Os alunos refizeram o primeiro artigo de opinião sobre o tema "Gravidez na adolescência: causas e consequências" em norma culta da língua ${ }^{7}$. Eles escreveram um novo texto. Esclarecemos que o termo "norma culta” é retirado de Faraco (2008, p. 73).

f) A proposta foi anotada no quadro branco pela docente da turma e assim estava escrita: "Escreva um artigo de opinião, em norma culta da língua, que será lido pelos leitores do jornal $O$ Povo. O tema do artigo é "Gravidez na adolescência: causas e consequências" Escreva no mínimo 15 linhas e no máximo 25 linhas".

O processo mostrado nesse artigo começou em 22 de agosto de 2016 e se desenvolveu ao longo de um pouco mais de um mês. Ele culminou na produção final em 28 de setembro de 2016. Foi feito dentro da sala de aula tradicional e também na sala de vídeo no interior da escola pública, com um total de 14 aulas de 50 minutos, em cada turno, manhã e tarde. Todos os alunos das duas turmas participaram, em um total de 65 alunos, e todos produziram artigos de opinião; no entanto, os textos analisados para este artigo somente foram os dos 18 alunos que participaram da pesquisa por adesão espontânea e cederam as suas produções textuais.

O livro didático adotado pela escola foi utilizado (pois havia nele textos relevantes e inseridos na realidade social dos alunos) para se trabalhar a estrutura do artigo de opinião e também para diminuir os custos e o uso de papel extra, já que $95 \%$ dos discentes receberam o livro didático gratuitamente. Para que os discentes conhecessem a temática pedida na proposta e para que tivessem mais conhecimentos que facilitassem a construção da argumentação, utilizamo-nos de outros textos escritos e do documentário em vídeo, relevantes por mostrarem algo real e por serem baseados em dados estatísticos. Os discentes apreciaram bastante o

\footnotetext{
${ }^{6}$ Publicado por Assembleia Legislativa do Estado de São Paulo em 2011. Fonte: site <<al-sp.jusbrasil.com.br $>>$. Acesso em 30/09/2016.

${ }^{7}$ Segundo Faraco (2008, p.73), “a expressão norma culta designa um conjunto de fenômenos linguísticos que ocorrem habitualmente no uso dos falantes letrados em situações mais monitoradas de fala e escrita".

${ }^{8} \mathrm{O}$ tema foi retirado do livro didático adotado pela escola cuja referência é: AMARAL, T. O. et al. Língua portuguesa, $9^{\circ}$ ano. 3. ed. São Paulo: Ibep, 2012.
} 
documentário "Meninas: gravidez na adolescência", de Sandra Werneck. Os textos escritos foram lidos com atenção na sala de aula.

Percebemos que nessa reescrita, a proposta anotada no quadro branco traz para o (a) produtor (a) do texto o incentivo de visualizar um possível leitor para seu texto. O possível leitor seria alguém que lê jornal, pois o texto seria publicado em um jornal de grande circulação. A reescrita após a intervenção se faz necessária para notarmos se houve alterações nos argumentos utilizados pelos produtores dos textos, se houve avanços no aprendizado da parte dos discentes.

\section{ANÁLISE DOS ARTIGOS PRODUZIDOS PELO ALUNADO ${ }^{9}$}

Uma das características da sala de aula das escolas públicas brasileiras, principalmente nas que são regulares, não profissionalizantes, é a heterogeneidade dos alunos. Diferentes faixas etárias na mesma sala de aula, diferentes histórias de vida. De um mesmo tema, cada aluno ou aluna produziu sua opinião, trazendo seu conhecimento de mundo para ter vez dentro de seu texto.

A escola pública estadual onde o trabalho foi feito localiza-se em um bairro da periferia, conhecido na cidade pelo histórico de violência. Atende o público de Ensino Fundamental e Médio. A escola possui quadra, cantina, laboratório de informática, sala de apoio psicopedagógico, biblioteca. Há 14 salas de aula e o estabelecimento funciona nos três turnos, manhã, tarde e noite. Atende principalmente ao público que mora nas adjacências.

Nenhum dos textos analisados ${ }^{10}$ mostrou um escritor ou escritora proficiente quanto à ortografia e correspondência com a norma culta da língua que foi pedida para essa prática de letramento. Houve vários desvios da norma culta; alguns não souberam defender a tese. Erros de ortografia e de concordância; erros de acentuação, de pontuação e a falta de elementos de coesão. Nos primeiros que foram escritos, existe um texto parcialmente ilegível (a docente chamou à atenção do aluno depois). Outros dois alunos copiaram o texto de uma colega (também foram chamados à atenção). Alguns não souberam defender a tese com a variedade de argumentos possíveis; outros nem criaram a tese no texto inicial. No texto final, houve um caso de não desenvolvimento da tese também, no entanto, não houve problemas com cópias, embora os erros de ortografia, acentuação e pontuação tenham se repetido.

\footnotetext{
9 Todos os nomes aqui adotados são fictícios.

${ }^{10}$ Os textos originais estão na seção de Anexos, ao final do trabalho.
} 
Notamos que o alunado do nono ano inicialmente encontrou dificuldades para redigir o artigo de opinião seguindo a estrutura básica desse tipo de gênero discursivo, dificuldades em diferenciar o tema da tese, em variar os tipos de argumento, em concluir o texto. Nada inesperado porque conforme Vieira (2005)

\begin{abstract}
Lidar simultaneamente com processos de composição e de transcrição, saber como gerar ideias e distribuí-las no texto, adequando-as ao seu nível de formalidade e propósito comunicativo, tudo isso faz com que a escrita seja uma atividade por natureza complexa e difícil, sem falar do manejo das diferenças próprias do meio escrito, face ao oral. (Vieira, 2005, p. 70)
\end{abstract}

Analisando os primeiros artigos do alunado, constatamos que do total de 18 textos, apenas 10 diferenciaram tema de tese. Os outros 8 textos, mostraram que o escritor partiu do tema, sem alterá-lo e não criaram um posicionamento a partir do tema dado. 8 escritores não desenvolveram a ideia central a ser defendida e 10 desenvolveram sua tese. 1 texto mostrou que o escritor apenas lançou argumentos por ilustração e causalidade para discorrer sobre o tema sem uma tese e tão pouco uma conclusão. As ideias das teses criadas pelos discentes giraram em torno de algumas ideias relevantes. 5 teses disseram que é comum os casos de adolescentes grávidas; 2 disseram que a gravidez na adolescência é um problema social; 1 afirmou que apesar das informações existentes, ainda continuam aparecendo casos; 2 falaram que a gravidez inesperada é complicada e gera conflitos familiares. A aluna Osana, em sua tese, declarou: "Apesar de tantas informações sobre sexualidade e métodos anticoncepcionais, as adolescentes continuam engravidando, e na maioria das vezes essas jovens acabam frustrando-se com a falta de apoio do companheiro que não quer assumir essa responsabilidade, e essa jovem acaba se tornando mais dependente de seus pais, que ficam com uma responsabilidade a mais" (sic).

Mostraremos os tipos de argumento que foram usados pelos alunos. Desenvolvemos a tabela abaixo com base em Fiorin (2015) e Gonzaga (2016) e a nomeação dos argumentos foi retirada dos referidos autores.

Foram encontrados os seguintes tipos de argumento nos textos iniciais:

Tabela 1 - Tipos de argumento que foram usados pelos alunos

\begin{tabular}{lc}
\hline Tipos de argumentos & n \\
\hline Argumento da direção & 7 \\
Argumento de prova concreta & 5 \\
Argumento por definição & 1 \\
\hline
\end{tabular}


Uma passagem bíblica utilizada como argumento

Argumento por causalidade

Argumento por oposição

Argumento por condição

Fonte: Elaboração da autora baseada em Fiorin (2015) e Gonzaga (2016)

\section{Definição dos argumentos surgidos no primeiro texto}

Definiremos agora cada tipo de argumento utilizado no texto inicial à luz de Fiorin (2015) e Gonzaga (2016).

Conforme Fiorin (2015, p.169), o “argumento da direção consiste em rejeitar alguma coisa, porque ela desencadeará uma reação em cadeia, uma perda de controle, uma consequência indesejada". Os discentes que optaram por esse tipo de argumento o fizeram na forma de uma frase de alerta, no final do texto. Por exemplo, no texto da aluna Letícia, ela escreveu: “... a maioria das adolescentes acham que nunca vai acontecer com ela (sic) mas sim, gravidez na adolescência pode acontecer com qualquer garota"; ou então como no texto do aluno Jonas, que citou a história de uma pessoa chamada Lúcia e concluiu seu texto assim dizendo: "E hoje ela se arrepende porque não usou proteção. Antes de qualquer relação sexual pare para pensar no que pode vir no futuro então use proteção, não seja uma Lúcia" (sic).

Gonzaga (2016, p. 166) diz que argumento de prova concreta é formado por “dados, estatísticas, gráficos, exemplos, fatos reais, leis, percentuais retirados de pesquisas científicas ou de fontes confiáveis". Uma das discentes que colocou em seu texto esse tipo de argumento, utilizou pesquisa do IBGE. A aluna Letícia escreveu: "Segundo os dados do IBGE desde 1980 o número de adolescentes entre 15 e 19 anos grávidas aumentou 15\%" (sic).

O "argumento por definição" é delimitado por Fiorin (2015, p. 118). O teórico diz: "as definições impõem um determinado sentido, estão orientadas para convencer o interlocutor de que um dado significado é aquele que deve ser levado em conta". Como escreveu o aluno Petrus: "Denomina-se gravidez na adolescência esse tipo de gravidez não planejada nem desejada acontece em meio a relacionamento e relações íntimos" (sic). Ao enfatizar que ela não é "desejada", argumenta para defender sua tese de "problema social".

Em um texto, foi utilizada uma passagem bíblica como argumento. Os textos bíblicos são regras incontestáveis para muitas pessoas. Fiorin $(2015$, p.120) falando sobre discurso afirma "Isso quer dizer que o enunciador, para constituir um discurso, leva em conta 
o discurso de outrem, que está presente no seu". Ao utilizar o discurso bíblico, a aluna Osana, quis que fosse um argumento de autoridade, algo que não pode ser contestado.

Fiorin (2016, p.149) destaca que "a argumentação por causalidade opera com dois grandes tipos [...]: a implicação e a concessão". O aluno Noberto, embora não tenha criado a tese, lançou alguns argumentos para discorrer sobre o tema. Ele escreveu: "Depende da situação se ela casar com o pai da criança e criar uma família, não tem nenhum problema. Mas se o pai da criança [...] não assumir a criança isso é um grande problema" (sic). Noberto utilizou um argumento por causalidade do tipo implicação "se a, então b".

O aluno Eliab, desenvolveu a tese. Ele escreveu algumas sentenças argumentativas acerca do tema proposto. Em uma, utilizou o que Fiorin (2016, p.137) chamou de "argumento pela oposição [...] o que significa que ele apela para o fato de que, se uma situação é vista de uma determinada maneira, a situação oposta deve ser considerada de maneira diversa". Eliab escreveu: "Bom primeiro que todas essas pessoas irão ficar surpresos, a jovem, pode ser expulsa de casa por seus pais ou pode ser aceita só por sua mãe e rejeitada por seu pai e pode até mesmo ser forçada a aborta pelo namorado por não aceitar essa pobre criança e não querer assumir o bebê e várias situação indesejadas isso é uma consequência. Mas também pode ser considerada tudo diferente na família da jovem [...]" (sic).

No argumento por condição, o próprio nome já implica sua definição. Fiorin (2016, p. 156) esclarece "Se...então". O aluno Davi, em seu artigo de opinião assim escreveu: "Todos os pais deveriam alertar aos filhos sobre as causas da gravidez na adolescência e suas consequências, principalmente se tratando de uma família de classe muito baixa, que não tenha condições de cuidar de mais uma criança [...]". Davi usa uma premissa condicional para persuadir o leitor: se a família é de "classe baixa" (sic), a criança pode levar uma vida de miséria.

\section{Depois da intervenção}

Analisamos agora o segundo texto produzido pelos discentes depois da intervenção ter sido aplicada. Dos 18 textos analisados, 17 desenvolveram a tese e 1 não construiu uma ideia central a ser defendida. A maioria dos discentes conseguiu diferenciar o tema da tese. O tema foi dado, a tese deveria ser construída. Como por exemplo, a aluna Quitéria, que a partir do tema "gravidez na adolescência: causas e consequências", formulou a seguinte tese: “A gravidez precoce é um assunto muito polêmico e preocupante no Brasil. As estatísticas mostram que, mesmo com os adolescentes dispondo de informações e métodos 
anticonceptivos esse número de jovens cresce.” (sic). A aluna Keila escreveu como tese a seguinte declaração: "Sabemos que na atualidade gravidez na adolescência é um dos assuntos que geram muitas discussões e vem sido apontada como um problema de saúde pública" (sic). A aluna Osana modificou sua tese, ainda que o tema tenha sido o mesmo. Ela escreveu: "As adolescentes não tem uma estrutura física e emocional, para serem mãe, mas com a mídia, as más influências, a falta de diálogo com os pais sobre relação sexual, elas acabam tendo relações sem a proteção devida com o pensamento de 'isso não acontece comigo' e fazem o ato" (sic).

Já o aluno Noberto, tanto no texto inicial como no final, não desenvolveu sua tese e isso não corresponde ao que se espera do gênero discursivo artigo de opinião, que pede uma opinião central da parte do autor e que será sustentada pelos argumentos. Isso dialoga com a afirmação de Gonzaga (2016, p. 165) "Sem a existência de um posicionamento claro, a argumentação será confusa e/ou ineficiente". O fato sugere que nem todos correspondem ao que é ensinado na sala de aula e isso é causado por diversos fatores, desde a falta de esforço da parte do aluno, ao fato das turmas serem numerosas, até a falta de um apoio pedagógico externo à docente da sala, como uma aula de reforço.

Resumiremos agora quantos desenvolveram a tese e quantos não o fizeram nos dois textos produzidos sobre o mesmo tema.

Tabela 2 - Quantitativo de alunos que produziram a tese

\begin{tabular}{lc}
\hline Tese & n \\
\hline Antes da intervenção & 10 \\
Depois da intervenção & 17 \\
\hline
\end{tabular}

Fonte: Elaboração da autora

\section{Definição dos argumentos que surgiram no segundo texto}

Os tipos de argumento mais encontrados no segundo texto foram:

Tabela 3 - Tipos de argumento mais encontrados no segundo texto

\begin{tabular}{ll}
\hline Tipos de argumento & n \\
\hline Argumento de direção & 2 \\
Argumento por ilustração & 8 \\
Argumento por causalidade & 2 \\
\hline
\end{tabular}


Argumento de autoridade

Argumento por prova concreta

Causa e efeito

Fonte: Elaboração da autora baseada em Fiorin (2015) e Gonzaga (2016)

Definiremos agora os tipos de argumentos que surgiram e ainda não foram definidos neste trabalho à luz de Fiorin (2015) e Gonzaga (2016).

O argumento por ilustração, conforme Fiorin (2015, p.188), "serve para reforçar uma tese tida como aceita. [...] Não se destina à comprovação, mas a comoção; volta-se mais para o sentimento". A aluna Irene argumentou apelando para a comoção quando escreveu a seguinte declaração: "Muitas jovens grávidas no Brasil falam que a gravidez as atrapalham de várias formas, a mais comentada por elas são por vergonha de irem para a escola com barriga grande por medo de serem 'zuadas' por amigos por serem as únicas grávidas na turma [...]" (sic).

Gonzaga (2016, p. 166) afirma que "argumento de autoridade é a citação de um especialista, de uma autoridade de determinada área". A aluna Quitéria assim defendeu seu ponto de vista: "De acordo com Rosely Sayão, que escreveu a reportagem 'Falta sexo", no estado de São Paulo, 36,1\% dos casos notificados de DST concentram-se na faixa de idade de 13 e 24 anos" (sic).

$\mathrm{O}$ aluno Miguel, em sua tese, disse várias coisas e dentre elas, fez a pergunta: “O que elas têm na cabeça de fazer isso com sua própria vida?" (sic). Ao utilizar um argumento de causa e efeito, ele disse que a adolescente "assumiu um risco muito grande para o futuro", que a adolescente vai abandonar a escola e o emprego dos seus sonhos por não ter se prevenido. É o que Gonzaga (2016, p. 166) chama de "argumento de raciocínio lógico", ou seja, aquele que "instaura conexões de sentido lógicas como causa e efeito".

Dos 36 artigos de opinião analisados, houve 13 menções ao abandono dos estudos por parte das adolescentes; os discentes mostraram-se preocupados quanto a essa questão. Também houve 9 menções quanto à falta de diálogo dos adolescentes com os pais como uma provável causa da gravidez precoce. Como exemplos, temos as afirmações de dois alunos. O aluno Fabrício declarou no seu texto: "Quando a adolescente fica grávida, ela abandona os estudos". A aluna Betina afirmou em seu artigo: "As causas dessa gravidez é a irresponsabilidade dos pais por falta de diálogo com os filhos".

Em 16 artigos, após a intervenção, os discentes tentaram construir ou desenvolver ideias que poderiam minimizar o problema. Por exemplo, a aluna Rania assim escreveu: “o 
governo pode ajudar com remédios [...] com campanhas [...] A família também pode ajudar aconselhando [...] a própria adolescente pode evitar que essa gravidez aconteça, se prevenindo, [...] (sic). A aluna Hebe disse que "o que o governo pode fazer é colocar mais atividades para ocupar essas adolescentes", os pais conversarem mais com sua filha e a própria adolescente aproveitar a vida saindo com os amigos certos. A aluna Quitéria afirmou: "Para reduzir esse número, o governo poderia aumentar a disponibilidade na distribuição de métodos anticonceptivos, ou até mesmo promover campanhas que dialoguem com a família para ajudar" (sic).

Nos textos percebemos que o foco sobre gravidez na adolescência é mais voltado para a figura feminina. A mulher ou é a culpada ou é a punida pela situação. Através dos textos, percebemos que para os adolescentes, o homem sai impune da situação. Ela (a adolescente) deve se informar, se cuidar, prevenir. A aluna Hebe escreveu: "a moça [...] fica em casa sozinha, enquanto o rapaz fica curtindo com os amigos" (sic). O aluno Petrus afirmou: "Depois da adolescente engravida vem as consequências e quais são? Na maioria dos casos abandono da família e depressão pós parto" (sic). Nem todos os textos falam das consequências para o homem. Na visão dos discentes, as consequências dessa situação recaem nas meninas, e quando os alunos não especificam as adolescentes, eles falam de uma maneira geral, os jovens. A aluna Betina, por exemplo, declarou: "Por conta disso jovens abandonam a escola cedo demais para trabalhar de maneira precária" (sic).

Somente um texto fez alusão a uma possível consequência para o garoto. A aluna Hebe afirmou: "depois que a moça engravida a maioria das meninas é obrigada a se ajuntar com o pai da criança" (sic). Quando se fala em abandono da escola ou estudos, sempre é a figura feminina.

Em pleno século XXI, a mulher ainda é o "lado mais fraco da corda" na visão discente. E não é culpa do alunado essa visão.

\section{CONSIDERAÇÕES FINAIS}

As aulas de língua portuguesa sempre trazem grandes desafios. Dentro do ambiente escolar, alguns alunos resistem a atividades de escrita, porque eles não têm consistentes "planos de escrita armazenados" (Kato, 1999, p.87) e consideram qualquer atividade de produção textual algo difícil. Essa resistência em escrever por parte do alunado (sem generalizações) é um desafio que o docente deve enfrentar e pensar em estratégias que 
possam levar a uma mudança ou uma melhoria em seu alunado. O professor precisa buscar formação e leituras que o ajudem nesta árdua tarefa.

$\mathrm{O}$ artigo de opinião dentro do ambiente escolar amplia as expectativas desse público em formação, no sentido de que eles podem ser protagonistas de suas histórias e tomar consciência de seus papéis na sociedade, não apenas como mais uma pessoa a ocupar um banco escolar, mas sim como pessoas que podem desenvolver suas capacidades persuasiva e argumentativa.

Desenvolver uma escrita diferente da espontânea, mais monitorada, que procura corresponder à norma culta da língua, é um exercício de estímulo para a competência escrita que todo alunado precisa buscar de modo que ele ou ela saiam da zona de conforto e da brevidade das palavras que as redes sociais tanto estimulam no alunado adolescente. $\mathrm{O}$ alunado de $9^{\circ}$ ano iniciou seu contato com o gênero discursivo artigo de opinião de tipologia argumentativa. Poucos trabalhos acadêmicos falam de pesquisas feitas com textos argumentativos no Ensino Fundamental.

Foi relevante trabalhar com textos argumentativos, pois esse tipo de texto estimula o raciocínio do alunado, e raciocinar antes de escrever, falar ou agir faz toda a diferença, porque como docentes, na escola, devemos formar pessoas para serem não somente alfabetizadas, mas sim letradas e capazes de se tornarem cidadãos e cidadãs que refletem e opinam. Buscamos mostrar uma possível prática de ensino que auxiliará o professor ou professora do Ensino Fundamental no exercício de sua prática docente, principalmente em aulas voltadas para o desenvolvimento do ato de escrever.

Consideramos que do primeiro texto ao texto final, houve uma evolução na escrita do alunado no tocante a corresponder ao que se espera de um artigo de opinião, havendo o cuidado em construir a estrutura básica de um artigo de opinião, com introdução, na qual encontramos a tese, desenvolvimento com os argumentos, e a conclusão, na qual o alunado preocupou-se em mostrar como o problema poderia ser minimizado.

O cuidado com a estrutura não foi percebido no primeiro texto dos discentes. Antes da intervenção, apenas 10 discentes diferenciaram o tema da tese; depois da intervenção, 17 diferenciaram e desenvolveram a tese. Houve a utilização de vários tipos de argumento na defesa da ideia central dos produtores dos textos na primeira e na última produção textual.

Mesmo não sendo objeto de estudo, foi impossível não notar que nenhum dos textos analisados mostrou um escritor ou escritora completamente proficiente quanto à 
ortografia e correspondência com a norma culta da língua que foi pedida para essa prática de letramento. No entanto, isso não é algo espantoso ou irreparável; é uma restrição de apreensão de conteúdo que pode ser trabalhada em aulas específicas para isso, a fim de minimizar o problema. Não é difícil nos depararmos com restrições no ato de escrever, quanto mais em textos produzidos pelo alunado de Ensino Fundamental. Estimular os discentes para a leitura como foi feito antes da produção textual é uma estratégia para amenizar o problema da escrita feita com erros ortográficos.

No entanto, o mais relevante foi feito. Não subestimamos os discentes do Ensino Fundamental ao querermos trabalhar com a tipologia argumentativa, algo que, na Educação Básica, muitas vezes é deixado para quando o(a) aluno(a) chegar ao Ensino Médio. A partir de um tema real e, infelizmente, até comum para a realidade deles, como é a gravidez na adolescência, o aluno pôde entrar em contato com a leitura e produção de textos argumentativos, criar sua tese e defendê-la, pelo fato de que compreendeu que é com argumentos que se pode alertar e persuadir a alguém. Alunos e alunas que a escola ajuda a transformar em cidadãos e cidadãs.

\section{REFERÊNCIAS}

ALMEIDA, D. M. V. de. Gêneros textuais [recurso eletrônico]: o que há por trás do espelho? Organizadora: Regina Lúcia Péret Dell'isola. Belo Horizonte. FALE/UFMG, 2012.

AMARAL, T. O. et al. Língua portuguesa, $9^{\circ}$ ano. 3. ed. São Paulo: Ibep, 2012. Coleção Tecendo linguagens.

BRÄNKLING, K. L. Trabalhando com artigo de opinião: re-visitando o eu no exercício da (re)significação da palavra do outro. Organizadora: ROJO, R. A Prática de linguagem em sala de aula: praticando os PCNs. Campinas, Mercado de Letras,2000. Disponível em: www.academia.edu. Acesso em 24/10/ 2016.

BRASIL. MEC. Parâmetros Curriculares Nacionais de Língua Portuguesa. Brasília, 1998.

CAVALCANTE, M.M. A argumentação persuasiva. In: Textos dissertativoargumentativos: subsídios para qualificação de avaliadores. Organizadoras: Lucília Helena do Carmo Garcez, Vilma Reche Corrêa. Brasília. Cebraspe, 2016.

DOLZ, J., SCHNEUWLY, B. e colaboradores. Gêneros orais e escritos na escola. Campinas: Mercado de Letras, 2010.

FARACO, C. A. Norma culta brasileira: desatando alguns nós. São Paulo: Parábola, 2008.

GONZAGA, E. S. Seleção e avaliação de argumentos. In: Textos dissertativoargumentativos: subsídios para qualificação de avaliadores. Organizadoras: Lucília Helena do Carmo Garcez, Vilma Reche Corrêa. Brasília. Cebraspe, 2016. 
KATO, M. No mundo da escrita: uma perspectiva psicolinguística. Editora Ática. São Paulo, 1999.

KLEIMAN. A. Letramento e suas implicações para o ensino de língua materna. Signo. Santa Cruz do Sul, v. 32 n 53, p. 1-25, dez, 2007.

KLEIMAN. A. (Org.). Os significados do Letramento: uma nova perspectiva sobre a prática social da escrita. Campinas, SP: Mercado das Letras, 1995.

MAGALHÃES, I. (Org.). Discursos e práticas de letramento: pesquisa etnográfica e formação de professores. Campinas, SP: Mercado das Letras, 2012.

NASCIMENTO, A. S. O gênero discursivo artigo de opinião em práticas de letramento escolar. 118 p. Dissertação (Mestrado em Letras). Universidade Federal do Ceará, Fortaleza, 2016.

SOARES, M. Letramento: um tema em três gêneros. Belo Horizonte: Autêntica, 2014.

Novas práticas de leitura e escrita: letramento na cibercultura. Campinas, vol. 23, n. 81, p. 143-160, dez. 2002. Disponível em http://www.cedes.unicamp.br.

STREET, B.V. Letramentos sociais: Abordagens críticas do letramento no desenvolvimento, na etnografia e na educação. São Paulo: Parábola, 2014.

VIEIRA, I. L. Escrita, para que te quero? Fortaleza: Edições Demócrito Rocha. UECE, 2005.

\section{A AUTORA}

Aline de Sousa Nascimento é Mestre em Letras pela Universidade Federal do Ceará, graduada em Letras Português e Literaturas pela mesma Universidade. Atua como professora efetiva da rede estadual do Ceará. Possui treinamento em avaliação de redações escolares e atua no projeto Café Literário, que promove o incentivo à leitura, com atuação na escola básica onde atualmente está lotada.

E-mail: alinesn10@hotmail.com 


\section{ANEXOS:}

1.

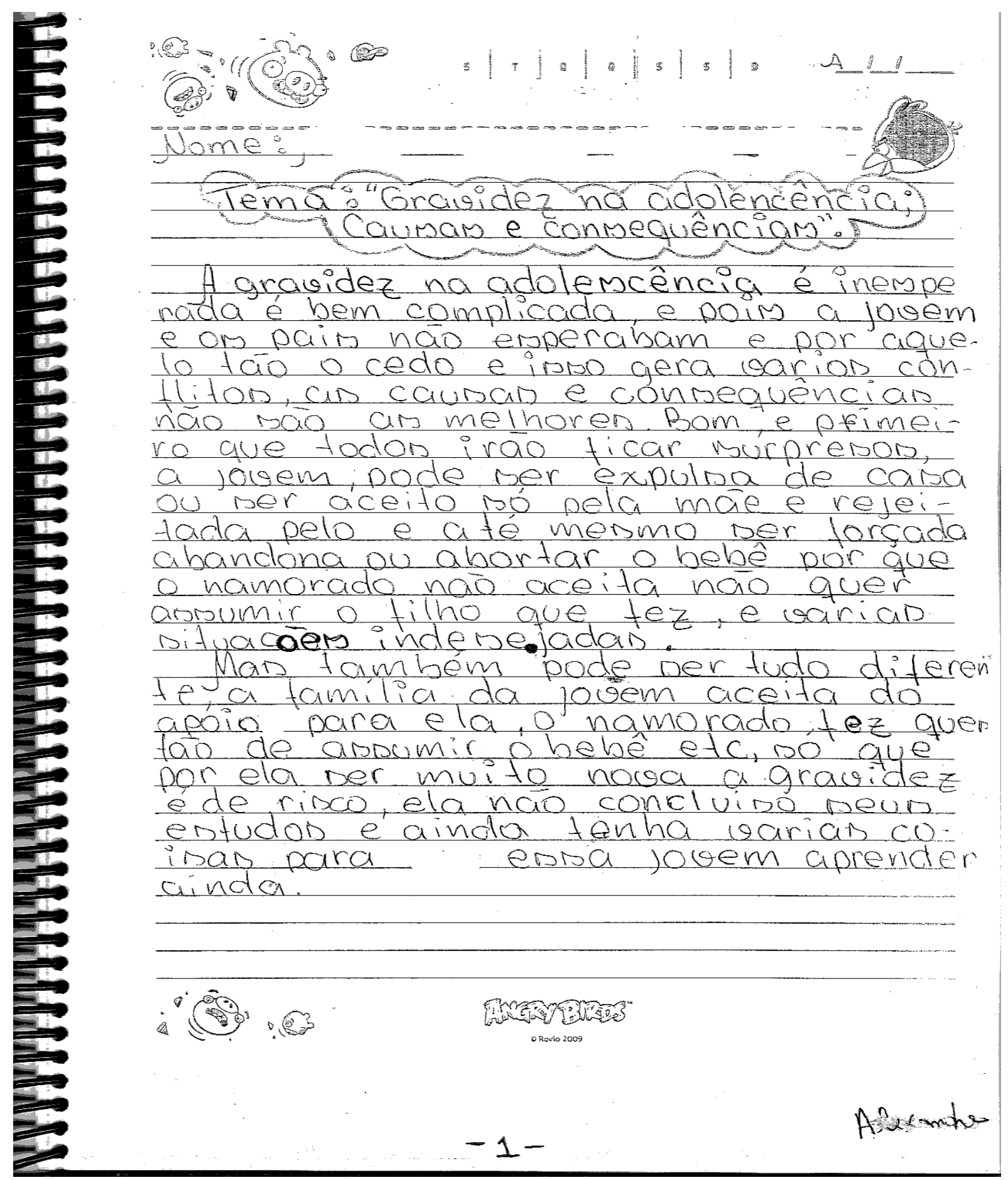


2

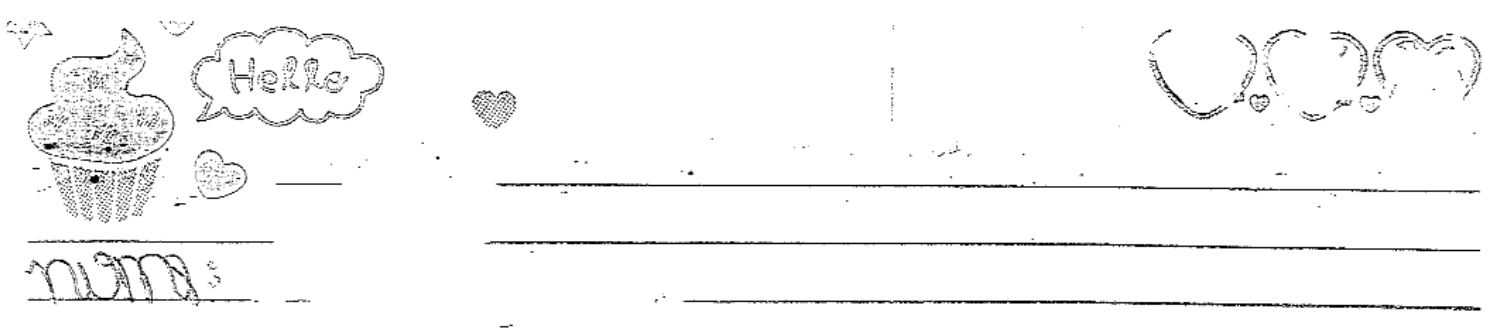

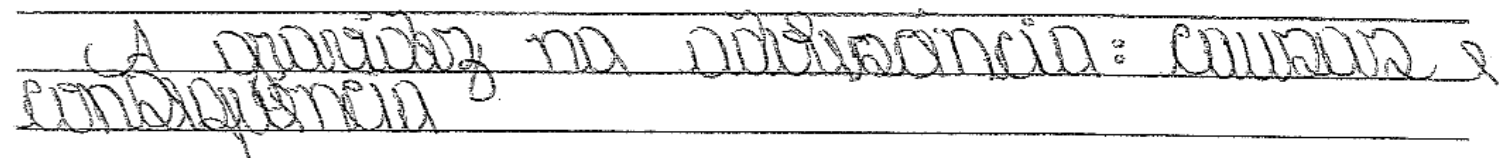

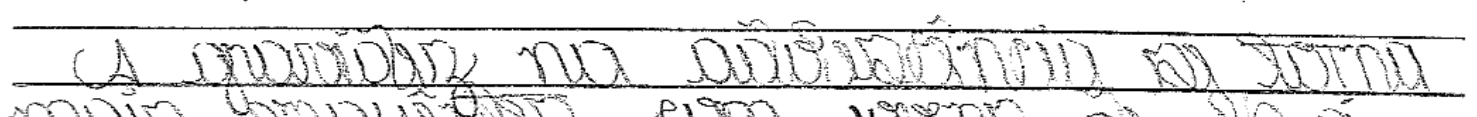

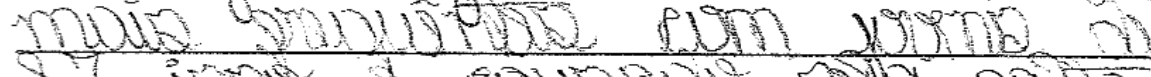

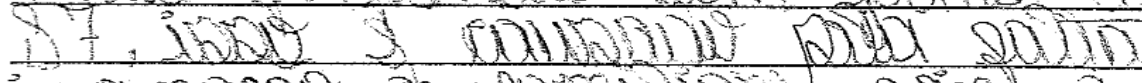

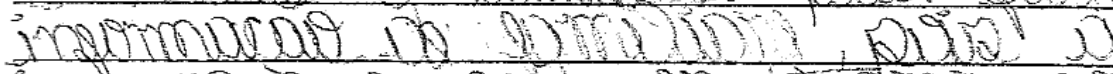

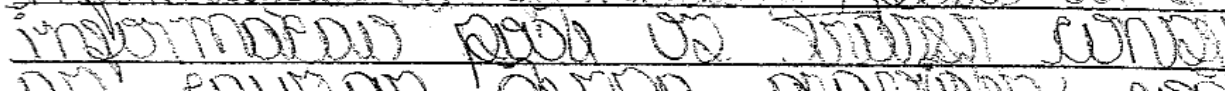

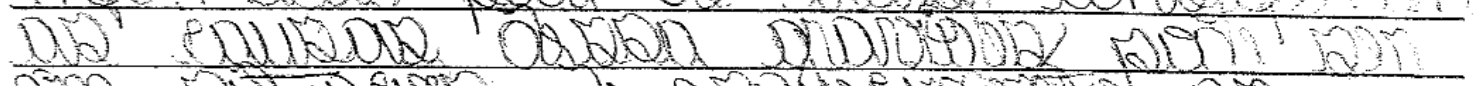

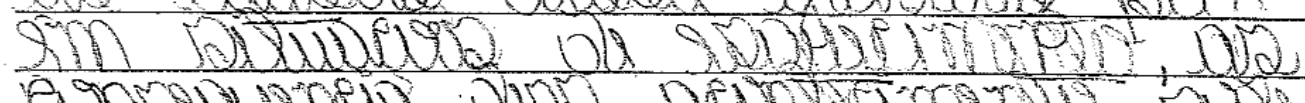

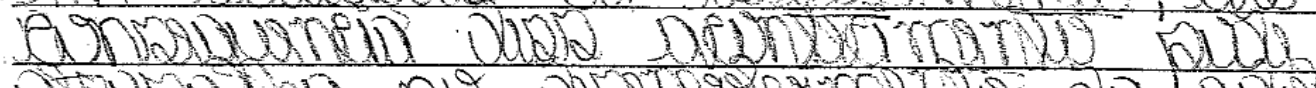

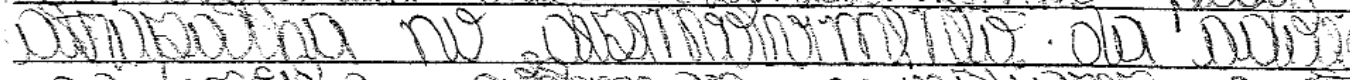

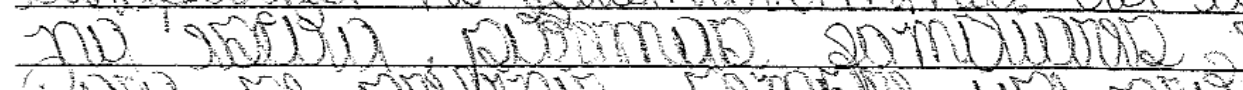

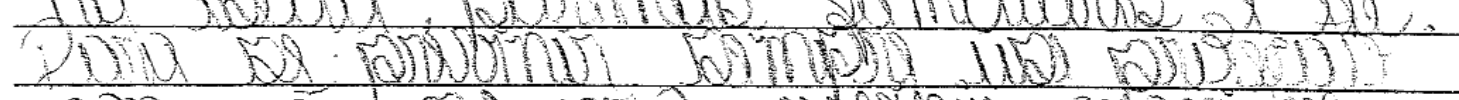

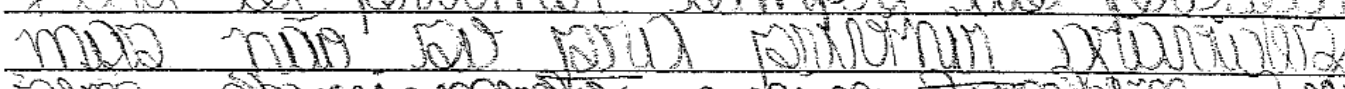

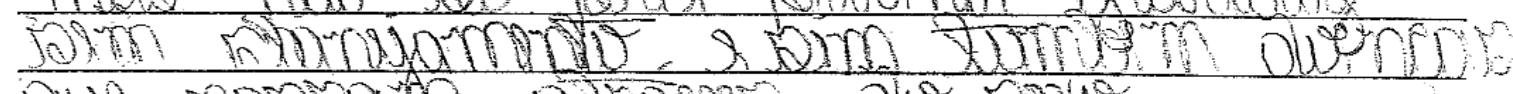

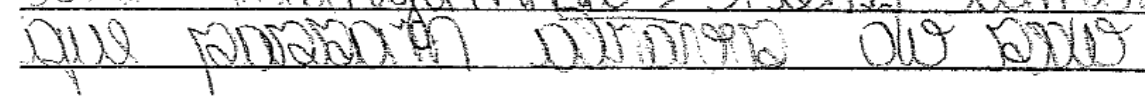

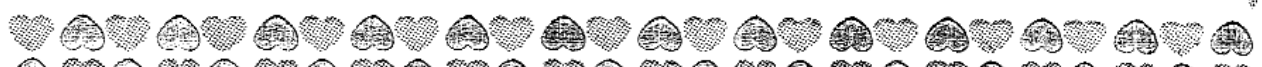

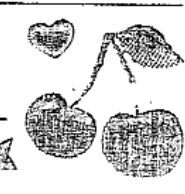

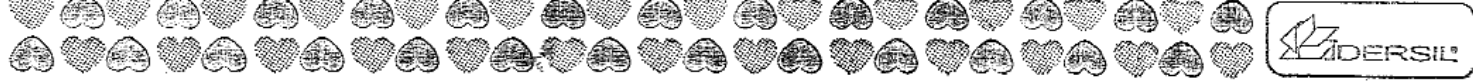

Bution 


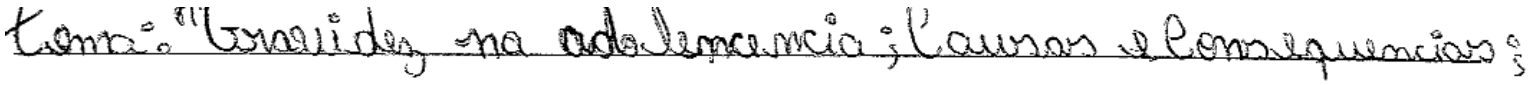

A gravides na adalincencia sinereperade shem emplicada u pais a fovem e vs pris nä esperabom U pir aquelo täa o cedo y irsmo gera varios comflitios, os causas ie comsequenciar niag vañ as umethares Bom u primuro que todas ivria fucar viriperas, a Souem, Pede rer expulta de cara au

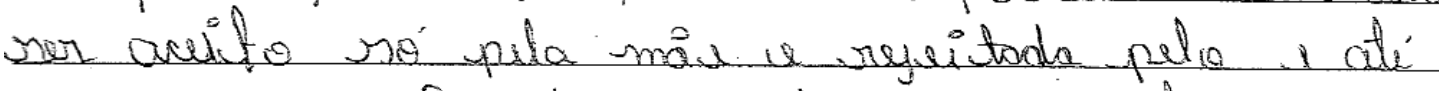

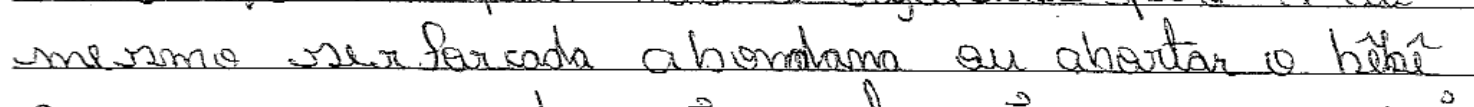
per que $\theta$ ramarada näa acuto man quer assuimir - Sulthe rue ty, evarias situracaer indersegado. Mas tamberm pade oser tudo difscumiter, a famulia do Sovum aceitla do apriedenara Mla o vamavado

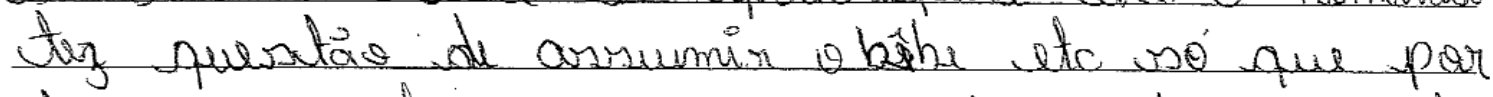
lla ver mutio nova a gravider a de rurco ella

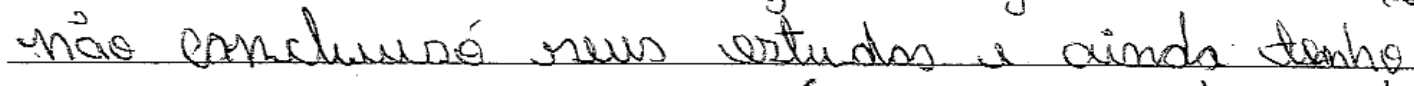
varios eavzas para ensa oveem aprende andse

鄫

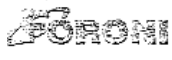

(3) Torancuinho Cotanina 
4.

Lemes.

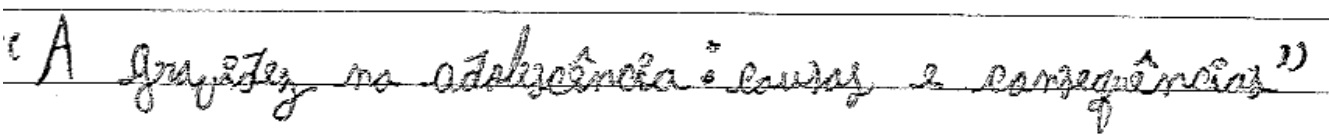

$r$

$\therefore \quad \mathrm{Am} D$

intar Te lon $2=0$

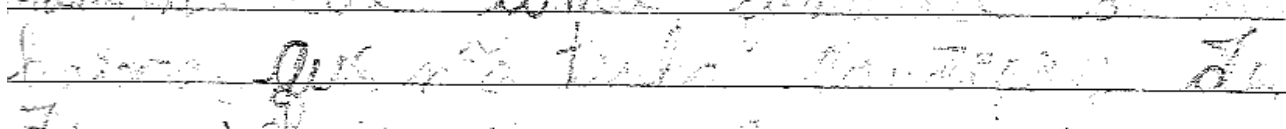

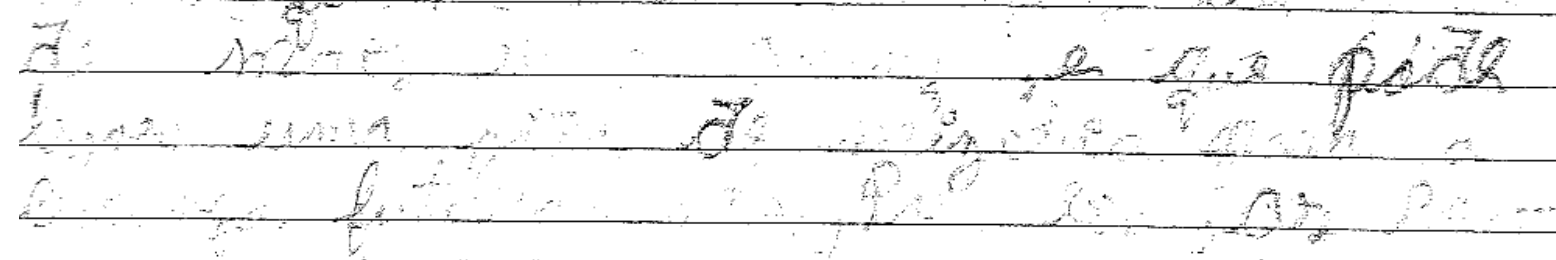

tine +9

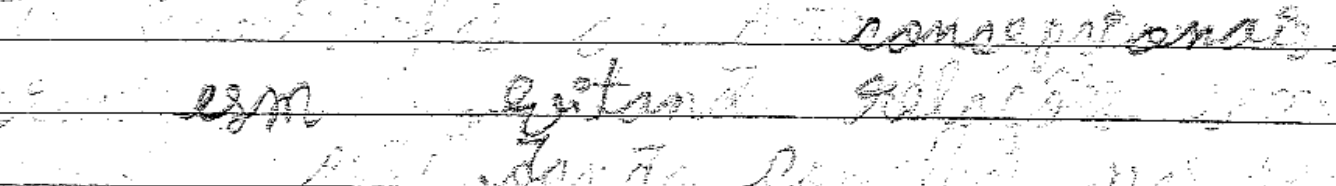

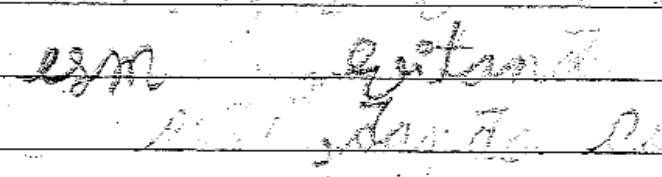

$5 \quad 2$ 
5.

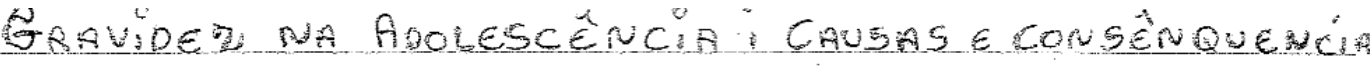
NOME:-

A GRAVIDEZ NA ADOLESCËNCIN É INESPERRDAE EM COMPLICAOA POŚS O JOVEM E OS PAIS NAOO ESPERAM e Por aquilo feito Tá cedo e isso gera Varios CONFLITOS NA FAMILIA. AS CAUSAS Disso GERA UMA CONSEQUẼNCiA NÄO SÄO AS MELHORES. BOM PRIMEIRO Que TODOS ESSAS PESSOAS IRÃO FiCAR SURPRESOS, A Jovem, PODE SER EXPULSA de SuA CASA POR SEUS PAís o. Pone ger aceito so pela SuA máe e ReJeitada POR SEY PAI $E$ PODE ATE NESMO SER FORCADA A

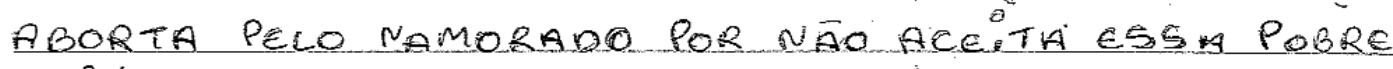
CRIANCA E NÃO QUERER ASSUMIR O BEBE E UARIAS Situacáo indesejadas isso euma consequencil. Mas tamben pode ser consederada Tudo dieErente NA FAMILIA DA DOVEM ACEITA DA APO:O PARA ELA AYUDA ELA NA GRAUIDET MAS CADA TEM SUA OPINinO SUA Forma oE olmir as coistas e ESG E Minma oriniño 
6.

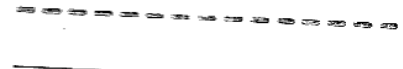

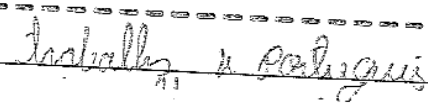

man:
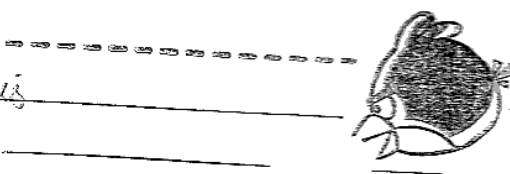

Graviziz ma

atalinancio

a

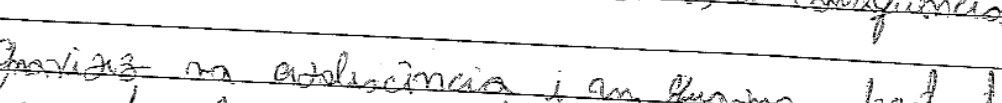

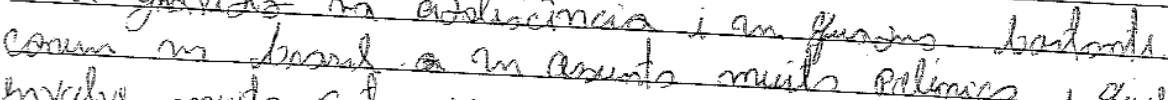

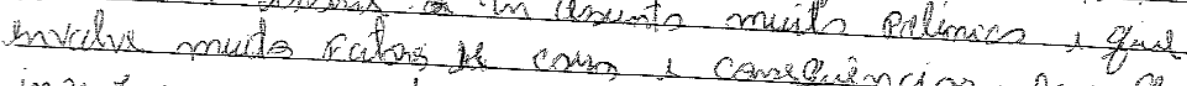

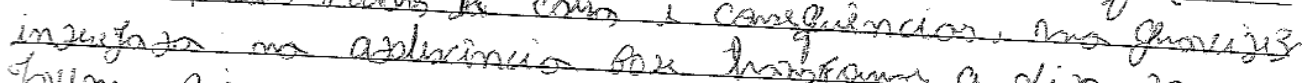

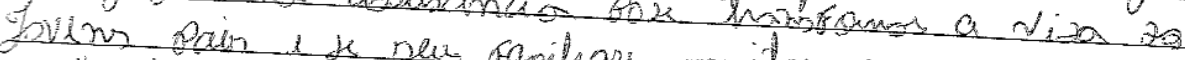

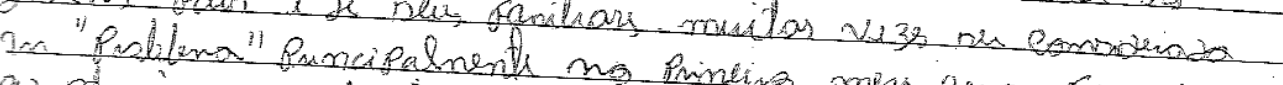

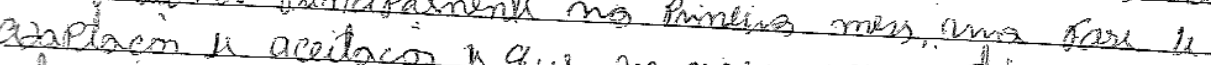

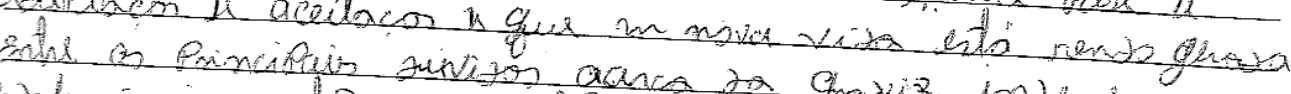

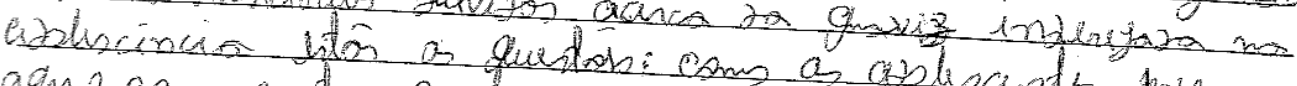

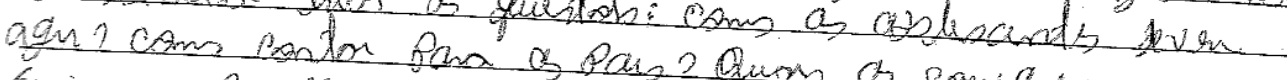

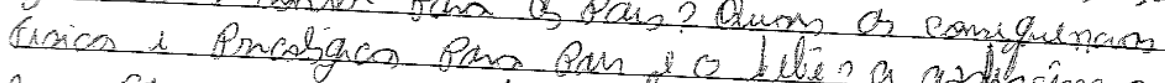

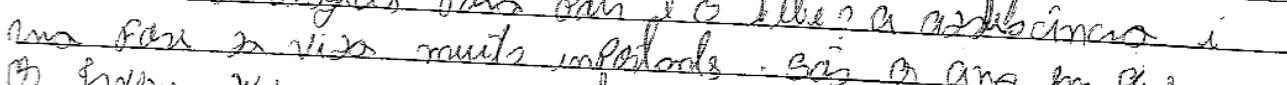

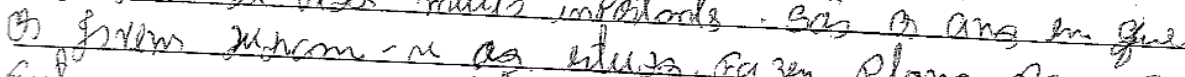

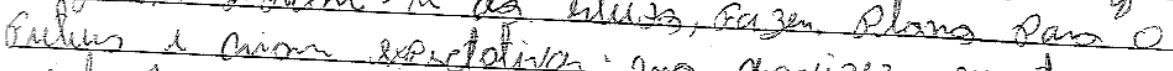

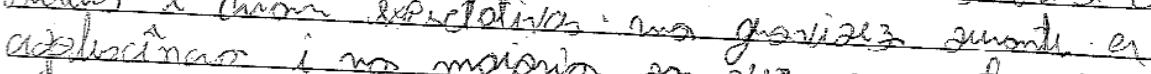

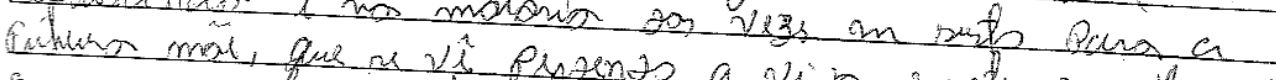

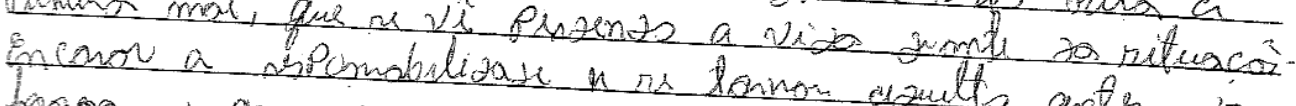

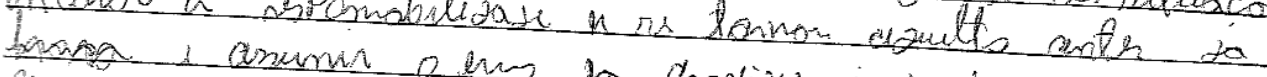

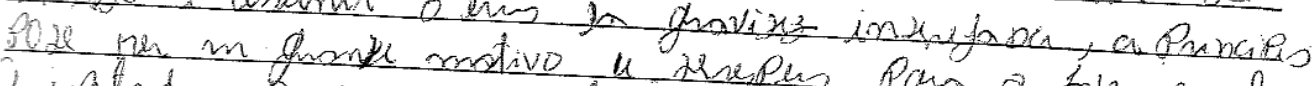

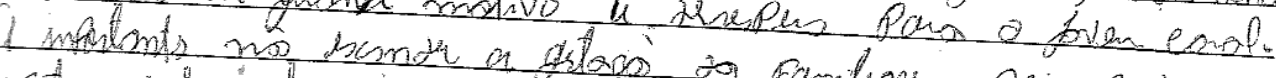

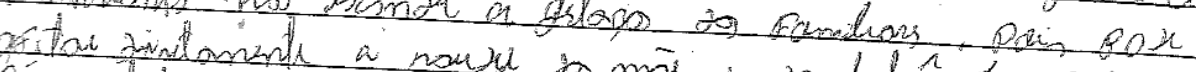

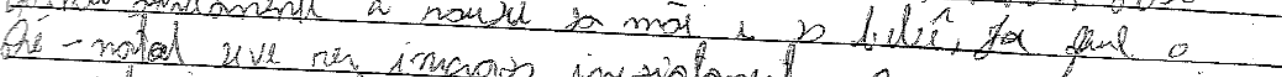

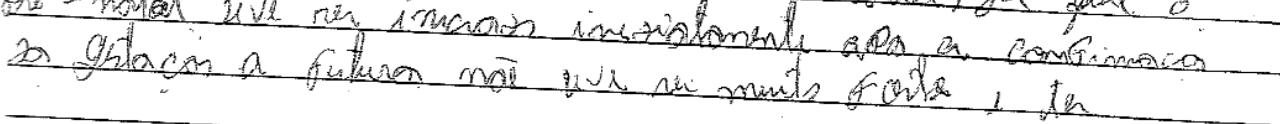


7.

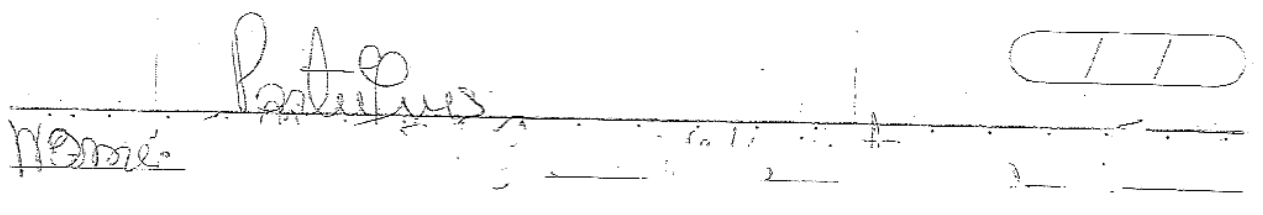

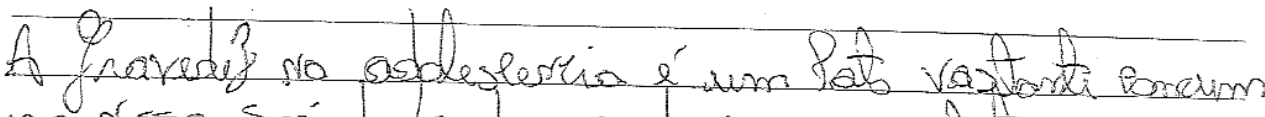

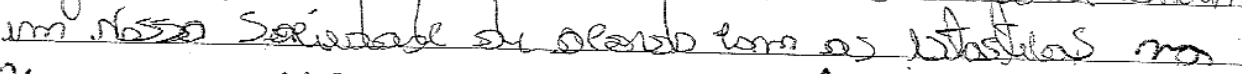

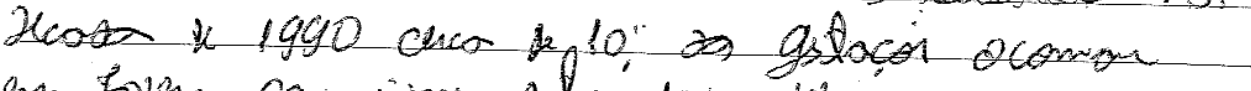
en jover car ijay enfu 10 a 19 ano boz ara kqun, ros ars 2000 , the nimes quon solinam

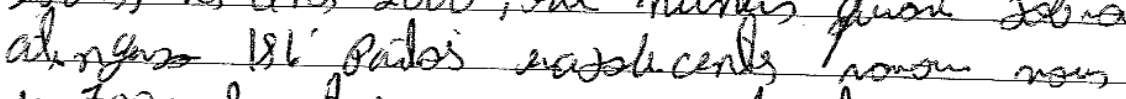
$4700 \mathrm{ml}$ tox os aro is linoul, en numirs muib expirmia.

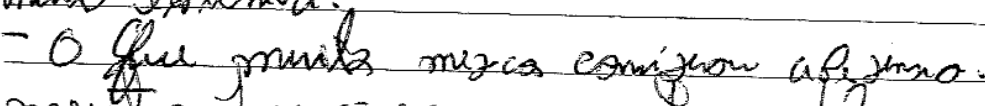

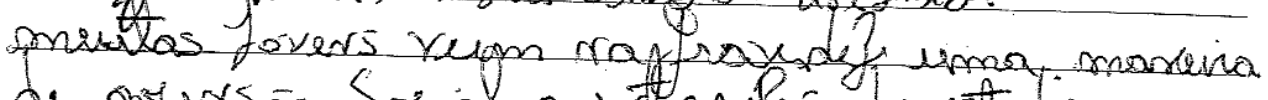

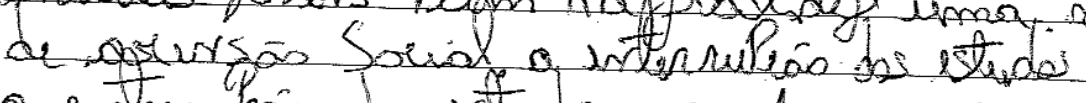

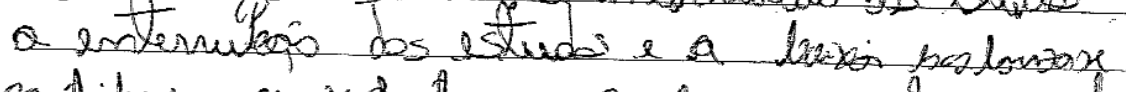

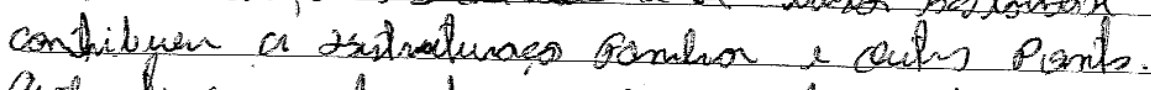

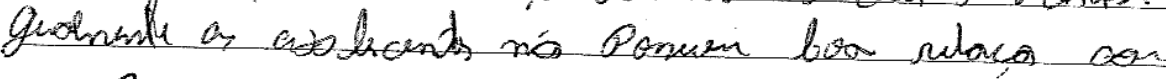
ren Guan

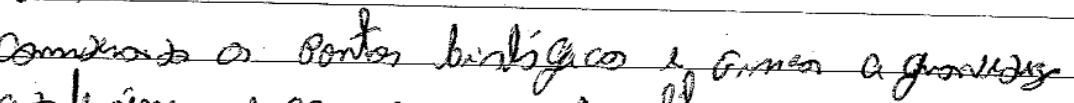

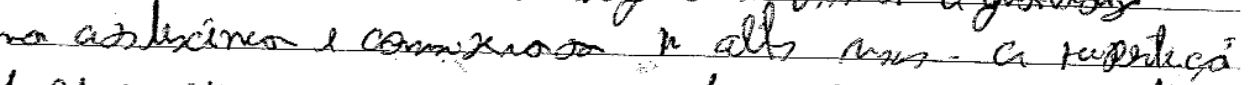

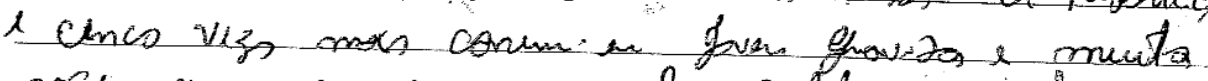

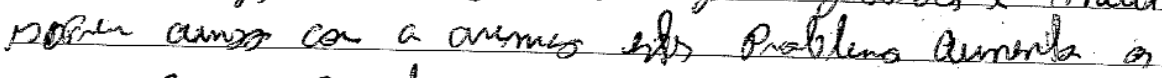

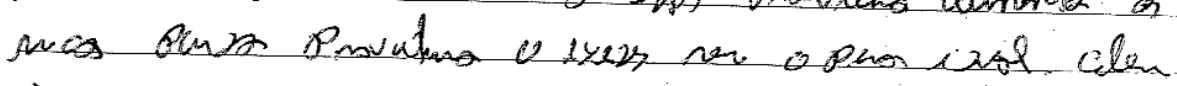
rucerizak enario. 
8.

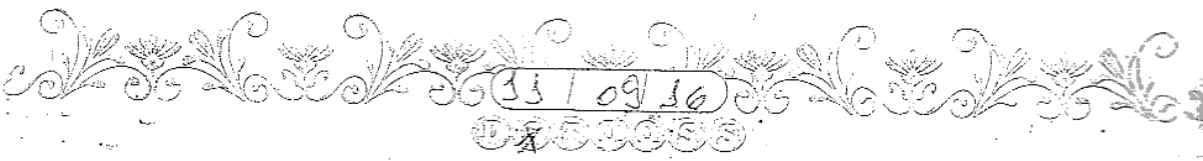

Inora $=$ Groviderer

odeduencis

Exciste alounos endicaü propriciom a ewa gravider, na adolecencia lutendo mithaves de frisen a ima expisiencia fora da hora/ dada imexperiecia e experiencia dificudado de em eridar do fitho que chega. Dentre os variodos patoresue celaberom poot aue ocara sse pernomene im sponde nimeror destocomas a falta de deptivios Emcontrados ne poituns de classe perral

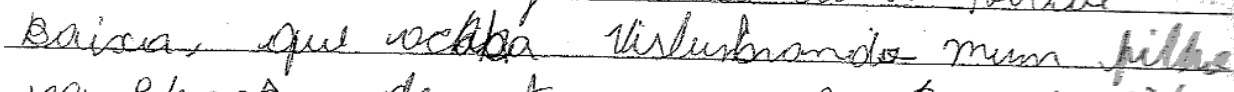
na Phones de ter un prosete de vida valém de encontra a epprtinidade de construis ama identidade mo ves uque naüa consegrír se inseri na vido propicion sectras lindicuex tanbin incontrada presenter na zida destapopulocaio que engrait. posse puiredo, tais come lares desenstruturados i lom pequenos nizel de emunica lono intre pais i pithos. 
9.

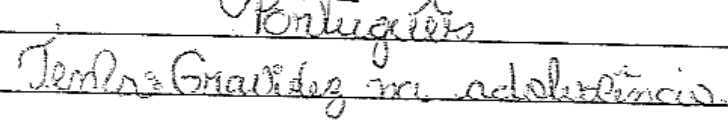

Pontroter

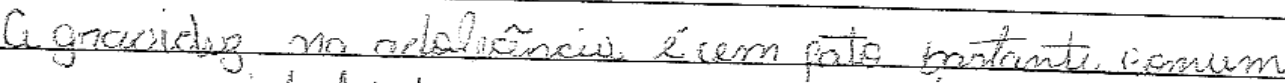

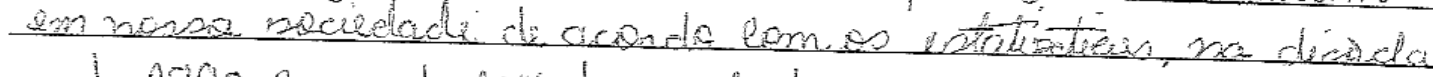

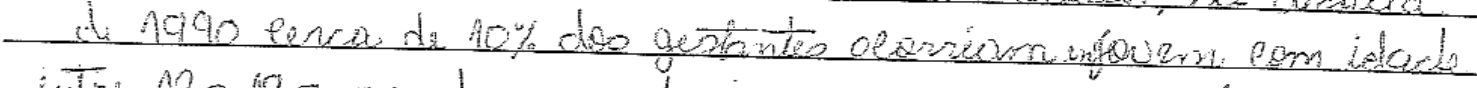

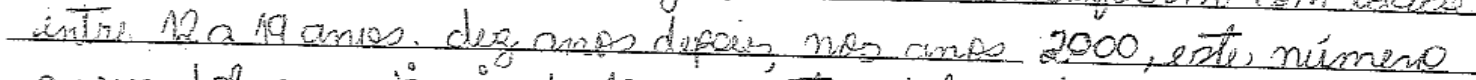

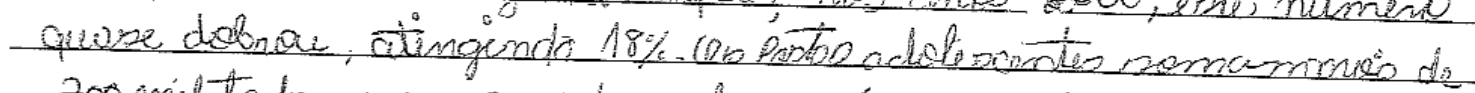

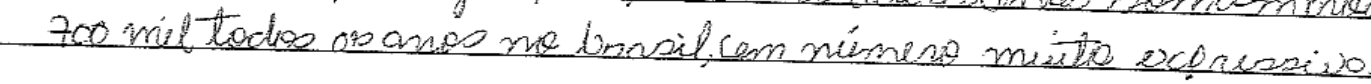

- Qque muiton mílikar considoan zoudimía. mizita foriens wivem na gnavinies uma manina de

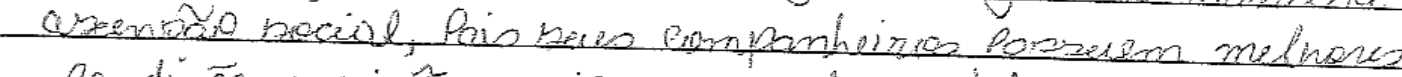

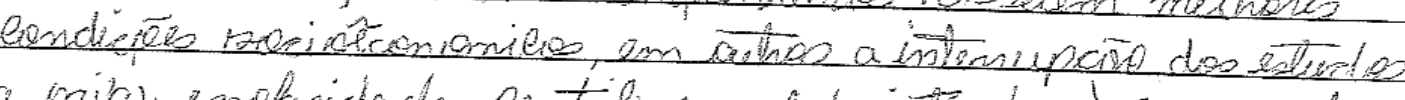

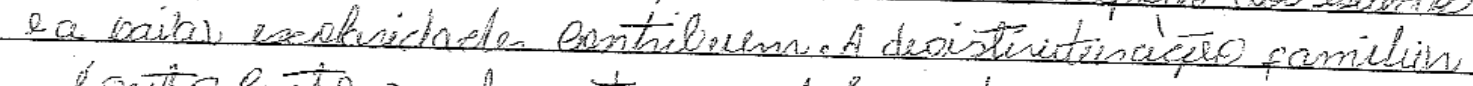

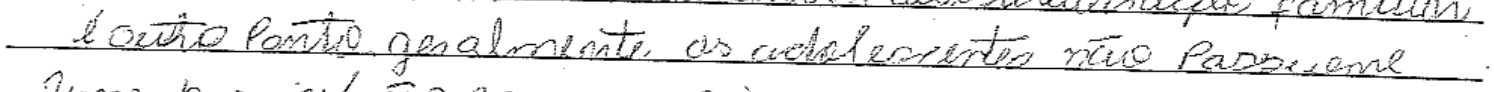

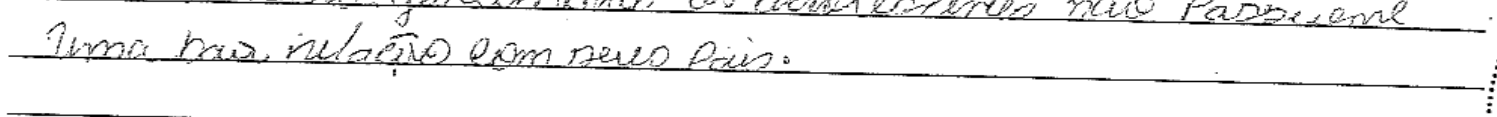


G onvidez. tor adolecona

- A gravide ra adolencia e rim problema nó só oqu no brasil, tnas emeda o pundo isso e um problema nó só para uina pessoa be impotar moa

Todos nos - por-que de nos nos unissemos para possor un póce de conheimerta para os fovens poatriamas amenizar os cosos a grovidez na oqovencia

- Levia tema menina de 17 anos e hojé tem 2 e la emgraviou quando tinha 15 anos. e-ná comsequiu estudar por que naia tinha comquerm.

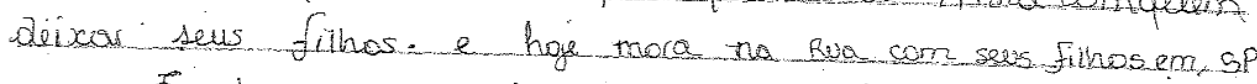
- E haje ela si arepende for que na usou proteción ontes de qualquer relarab sexcual pare para pensar no que pade uir no füura entáo use proze cáo nai sya uma deutia 
11.

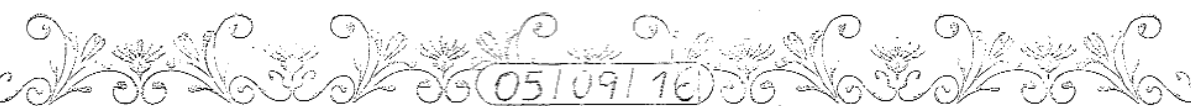
(口) - eses

* Antigo de opiniáo: Tema:

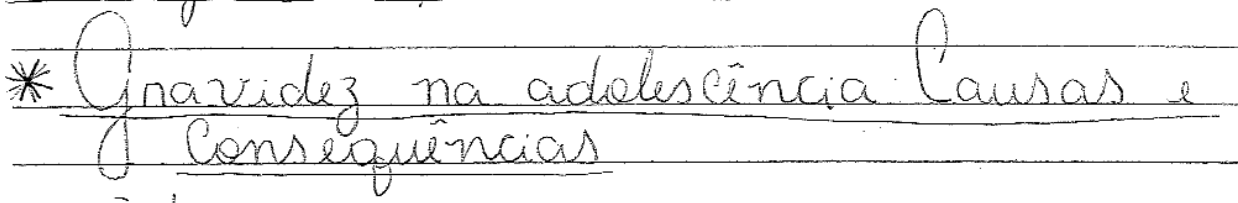
Im dos mairus fatores cavsadows da granidez na adoleseinlia a a falta de informacão corrase todos is adoleseintes nẵo se importam de $x$ informa solve as consequencias como a maturichade, sera ave um avioleseinte ímaduro o sufilente para hidar de uma erianca, de undar das dispesas, e tambim muitas das vezes iss adidenêrite é expulso de lasa.

O maior numiño de adolislintes gou enaravidam kivem now runas s a maioria abondona es filhos a a garneta Gou fica responsável pelo Bione. Gnavidez na adolescencia é um ris ca para os pais e para o Bểî. Rividar de vma criomca nầ é facal, prinlipalmente asuando, voci mão i maduro Q scifiliente para saber as consegainlias an para aspumi-las

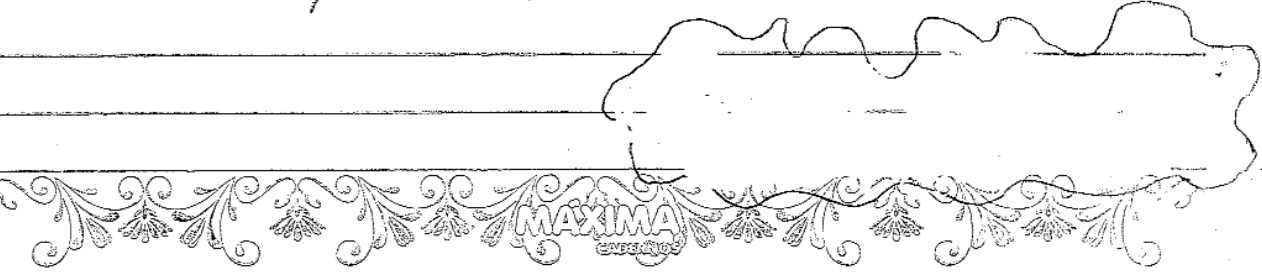


12.

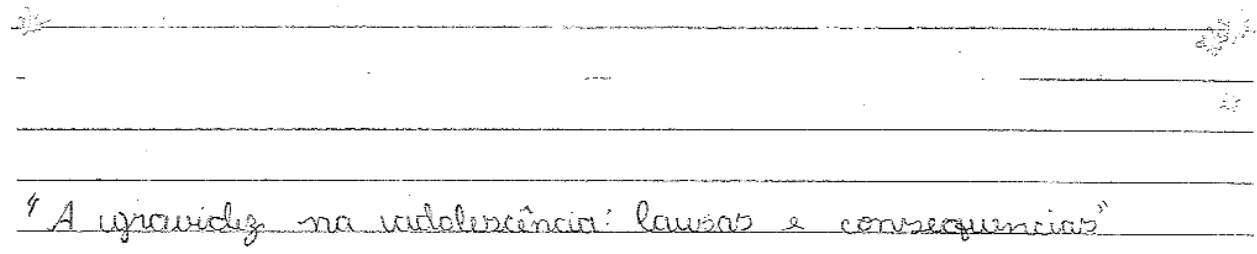

Sim, vamos abordar vo tema growidez na vadolencencia!

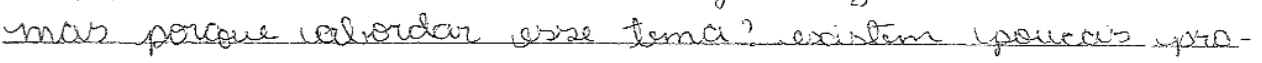

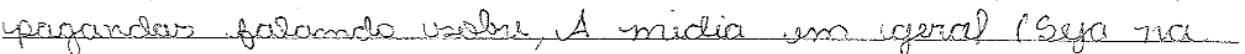
telinado internet ou campanhaz) vempirs enfatiza a graviHeder na iedolazencia e a pressuncaso.

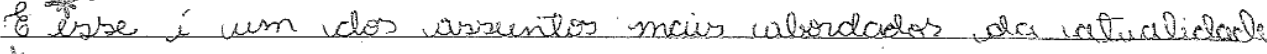

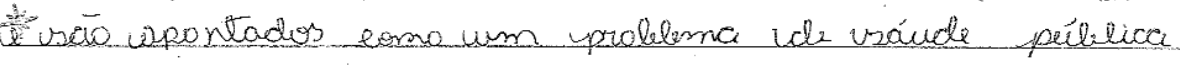

2. erze numero ná̃ spara ude ereser. Segundo vers darlos

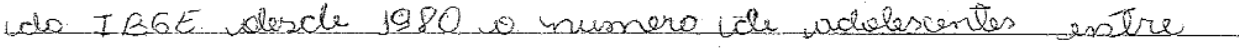
15 \& 39 anos gravedar wumbertion $15 \%$

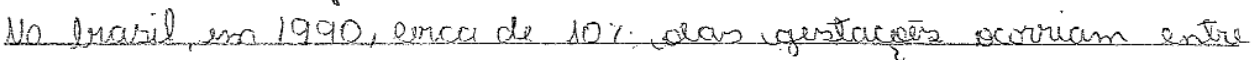
12 , 19 anos.

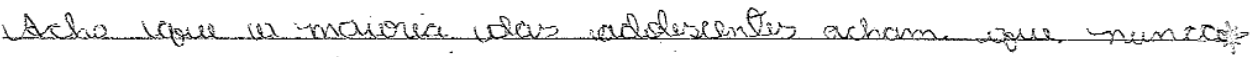
wai acontzer coner ela

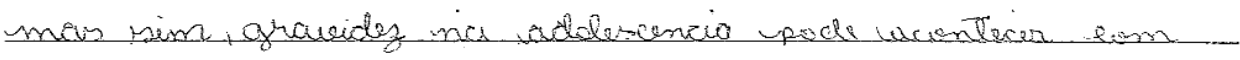
vequalouer agrota

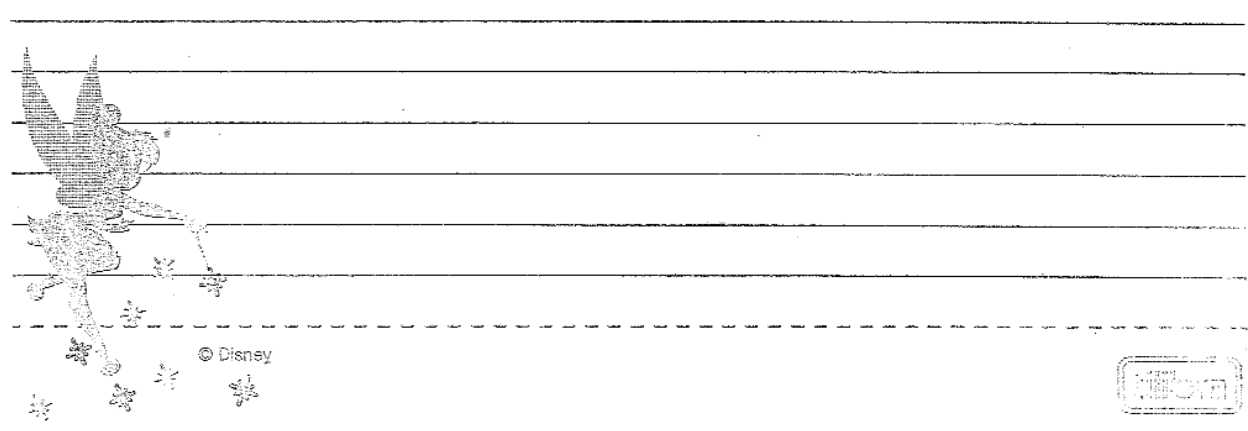

Leficio 
13.

Produzor un arvego de oppinuó

"A grauidez na odsennevo: Careva e cansequencioo"

Q graviduz na odblezencias uma dar poucar coirarz que cominfad no mundo, ruma pezquiva que wá wio as tarér de graiduz ufa ocorrido na poira de 10 a 15 anos, Mas mudiolminte, ilaria infre 143 para 1000 na ligriea sebsoarianov, a 2,9 para 1000 na carua doses$\ell$.

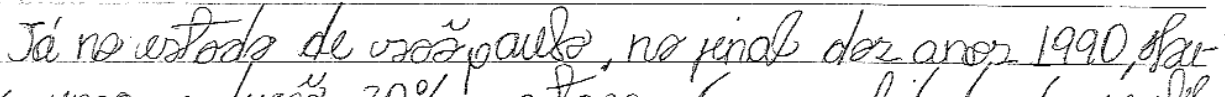
us una redurö $20 \%$ natara de sexualidode dasmelst-

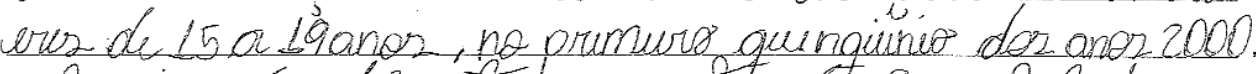

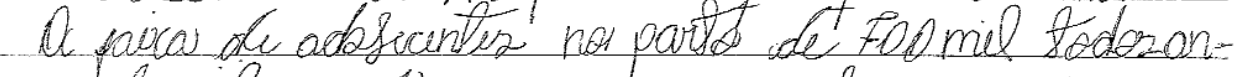

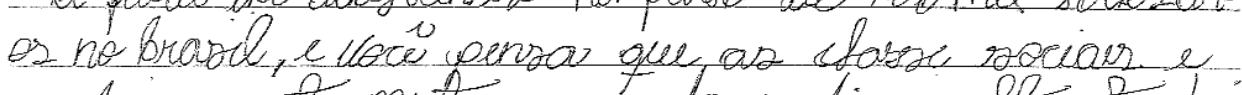
so baver ista mulo enganando medior calfar tambin

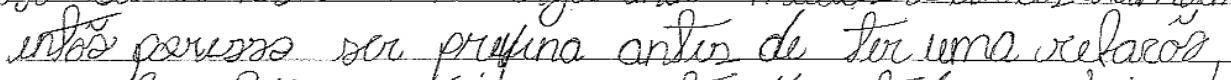

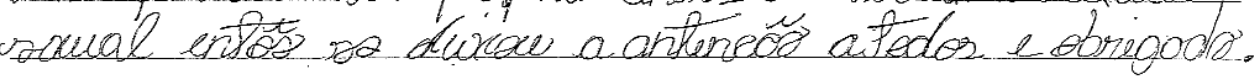


14.

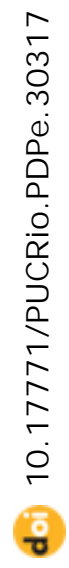

Depónde da Suturango se ela se

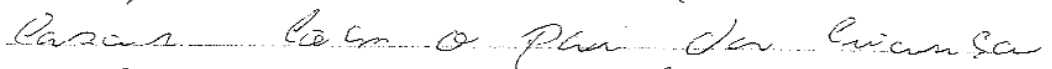
e. Uniar ucma fanulia nta tean

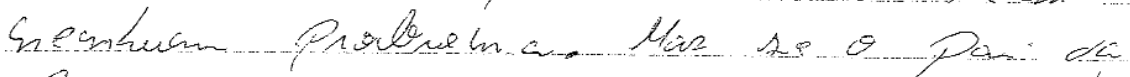

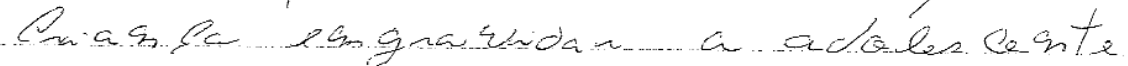

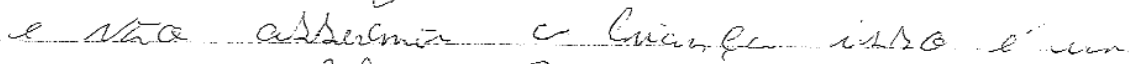

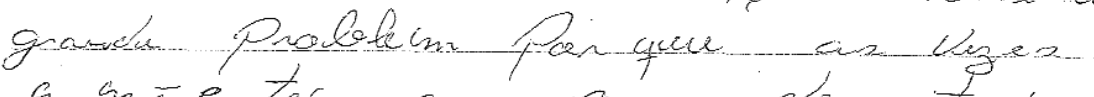
a inãe tem cuse prara de esturdar

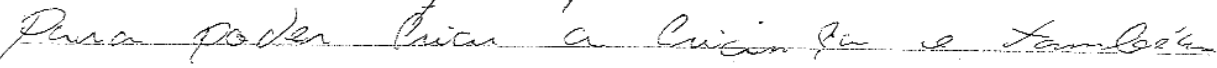
ahorarjar un ebpreg e para paden ... Serstertar ofulha

$$
-14-
$$

A.t. 
15.

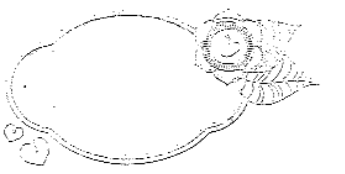

Toravidez na didolecencia: cactata e contequencia G

Gravidez na adolecéncia falta in intormaczo? Apesar de tant informacoés sobre sexuadidade e métodas anticoncepciona is aci

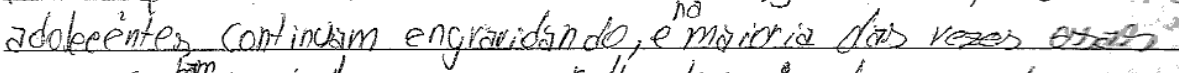
porens rican frostando-secom a falta de apoio do companheiro as

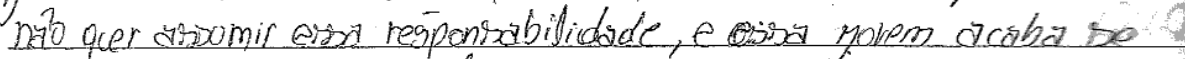

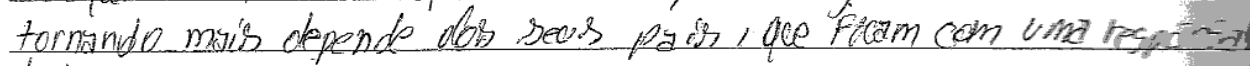
dade त maly.

Os yovens muitas vezeos negam o rinco de engranidar devido can

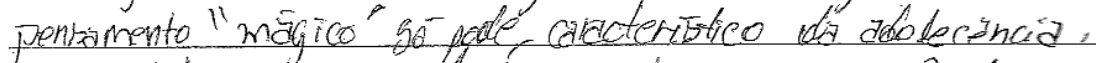
imatumide privemociand E a gravidz precomem tem allos

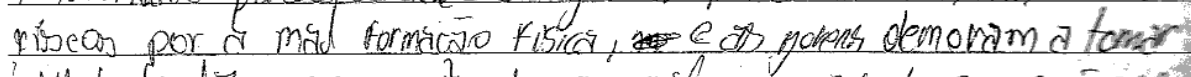

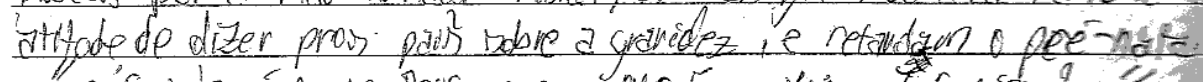

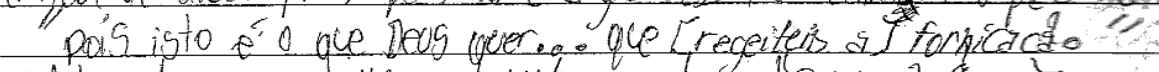

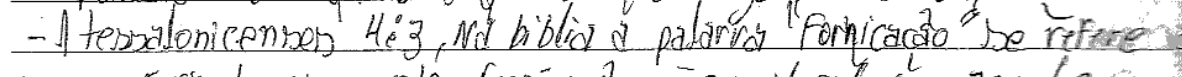

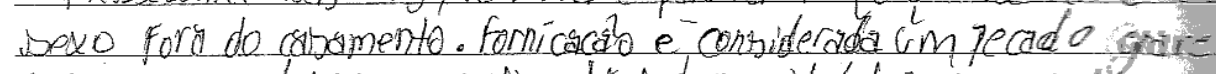
dissim como adutério, espiritcomo behedeura, ido latrig, dsedsinat to e noubo:- 1 corintiog 6:9,10: Relelaca (Apocaliphel21:8.

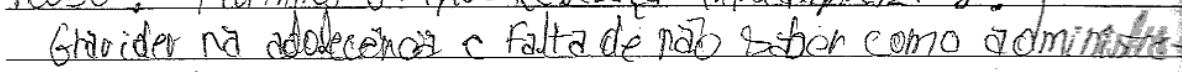
corretamente.

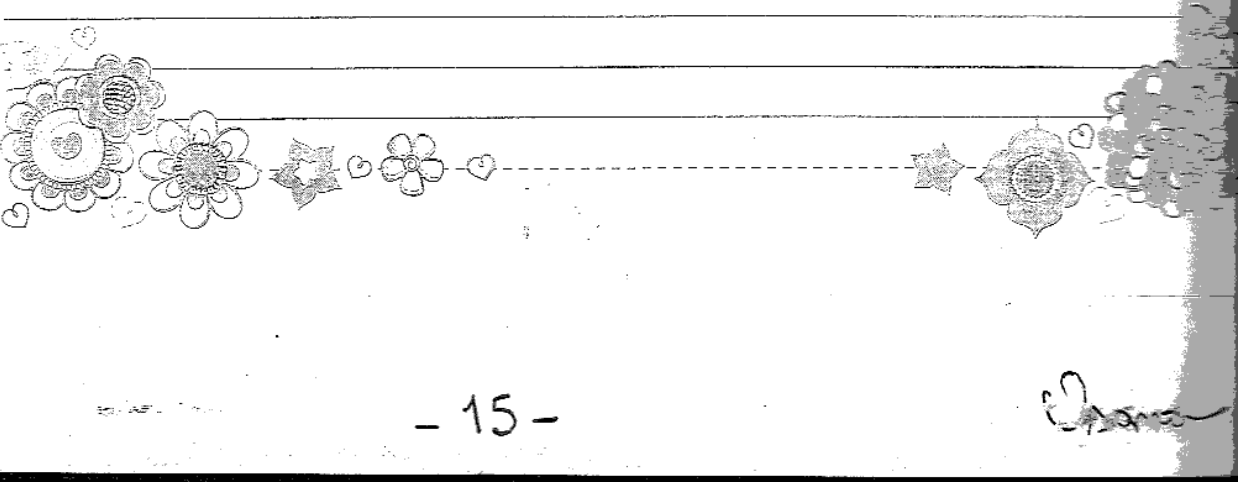


16.

proatuguers

$00-0-000$

texte. i groureder wna adolecer endio equsa e consegunkia" tere.

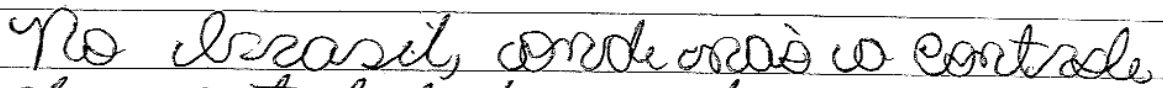
de natoledode onde o vassuntes forciliar e a educaeá sercuab saó parces descutido's, a grovkielezes aeabia rse teornondo muttos vises um yprolclema. sscial grabe a ser resolecido ¿ $\theta$ cose da gratidez na cocolecercia. Denvamana- se ograviolez na iodeslecricio uspe tepo ole grovediz una planajada nem desyada vacontier cem recia a nelacionamente u ricla. eoès unctemos. Vo lirasil cos numeros sas aloamenctes.

Caliese costacor tombem a gaoveidez apen i ium peralclimo cescleisurs entre uneramos. 
oue una fossum londican lado. go fora ruidor de um fillo 
17.

Pontuguars- Antigo de coinião

toma:

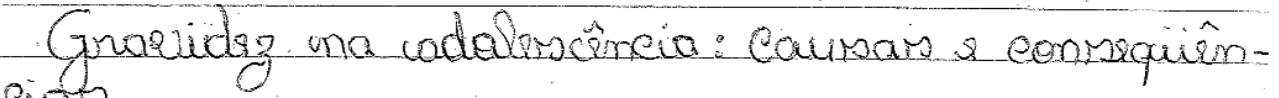
cions

gravsids una adabrocencio śum fato umuito cornum nos dior de hols, sum arsuento bastant

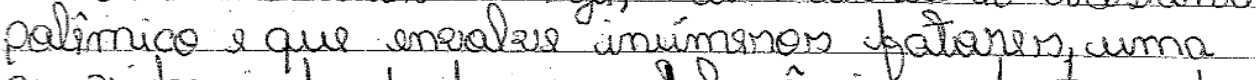

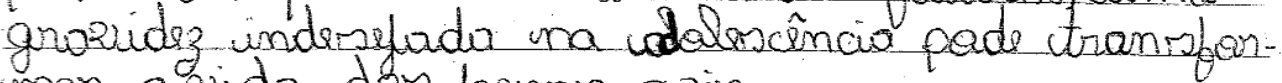
man ca zida dor fovemis pais.

Do vacardo com ars rstatísticass ma décado de 1990 cerca de $10 \%$ das gurtaçoss ocorriam em foziens com idade entre 12 \& 19 ános. Drz canor depau, mor conor 2000 , rsts númono quars dabrau, vatigindo $18 \%$ Os partor em adaliscénters somam imais di 700 mil Tador iors conor uno Brasil, um unúmero muito expressizo - o que muitor unśdicors consideram spuidemio.

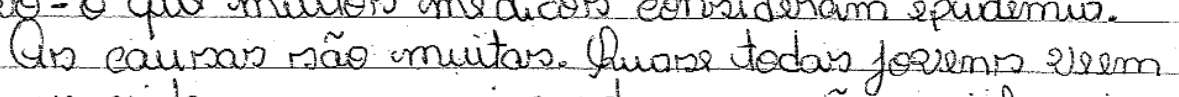
na grovidez uma maneira de arcennão social, pais mews puncuror, muitas wszer, porsuem umlhores con-

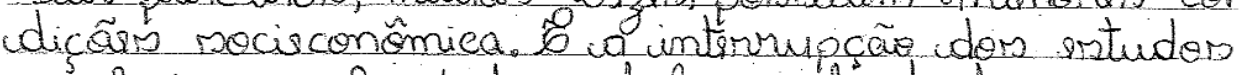
\& ca baixca siscalaridad contribium bastants.

A dessatruturacáa familiar ś cutro ponto. Geral. mente car cadalersếnters uño porrauem bou rulaço com

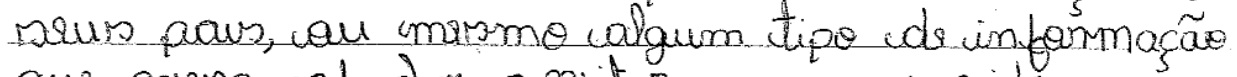
que ponsa cafudur a selitar uma gravidzz. Cém dars unstrucáss uño dadas pala familio iau umermo pela siscalá (par conta das palíticas puliticas). Muitas zogro a conzunisa com a famílio unäo śmuito facil, par zario imatizer, in cluindo também $\theta$

$$
\text { 17- Quitino }
$$


dificl dialogo entre pais a fllhor, unuitas 20385 tambiém pon zalorer mociais, zalorer familianrs, raligionor a sto.

Comuments conhecida como primeipal consequância * abandono é rscala. s a pordo dos upartúnidads que paderio ter ono futuro Outras consequencio

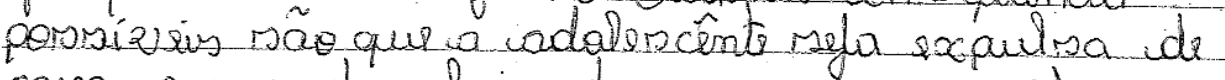
cara cou rendo abriguda la easar, \& unuitas

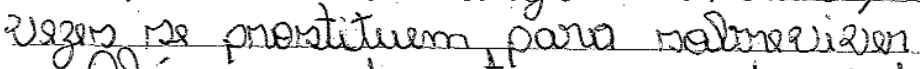
Olém qus, udunante a grovidss śdifieil manten a sida normal como antrr. Qutra consequêncio ś perder toda a adolenciencia, terndo qu, em alguns casors, trabaltar para rustentar su filho.

\&. considerando cos pontor stialógicos séricicors. a gravlidg una adalreséncia é conviderado ide alto visco. A nipsertenrõa í einco vszers mais comum em fovsm gravidars i muitas winda rafrem eom a angmia.

Então nâo tenha vssrgonha/medo de ir una farmácia comprour proserzatizion ( au ir no posto fó que

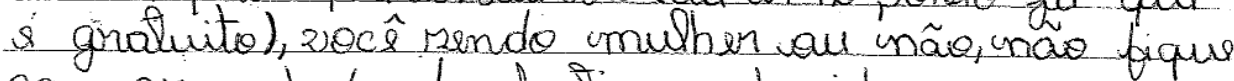
com vergonha/medo de tirar duzidas ou conver. saz com seur pais rabre rsca. 
18.

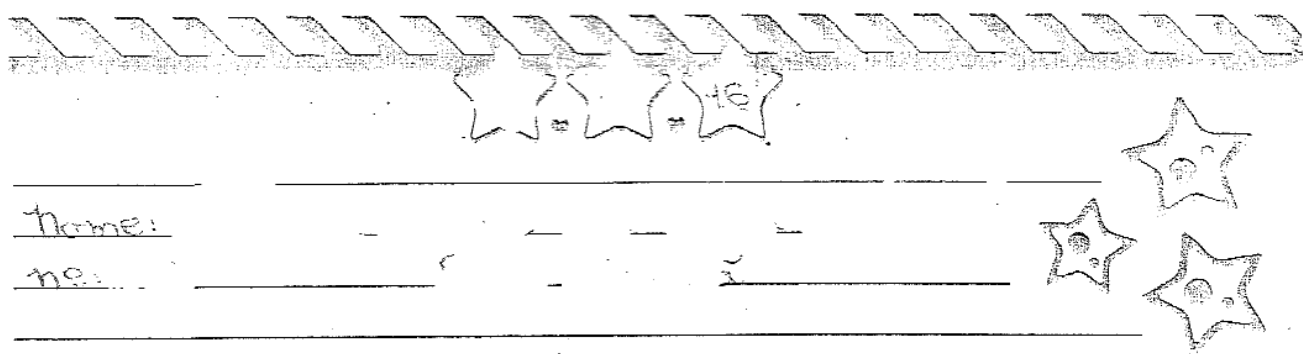

Produzin um amitico de opinirio

"A gravidez na adolescếncia:

ealsinar e connequéncion

Bom cuemo comegar falando que evoe mobunto Za be fomnando cada vez mais samim em fodo o Bmasil. Dain hoye em dia em todor as livanes tarits encontmamots tonerinas ha faixa ezamia de 12 a 16 anow grävidas com o bucho pelam goela. Sem 7 er condicá de cuidar de wi mewma, imagine de uma cmiancia

d Main tamben imo acontece por pe elas queHem pois ná falta connelbow das perascas

Entás na minha opinis̃o meninats desorar idaden devem exza na excola e nao nas muas fazendo o cue náo pmeriza

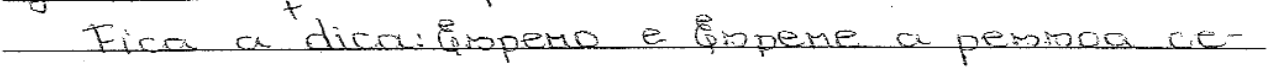
Mita e a homa centa
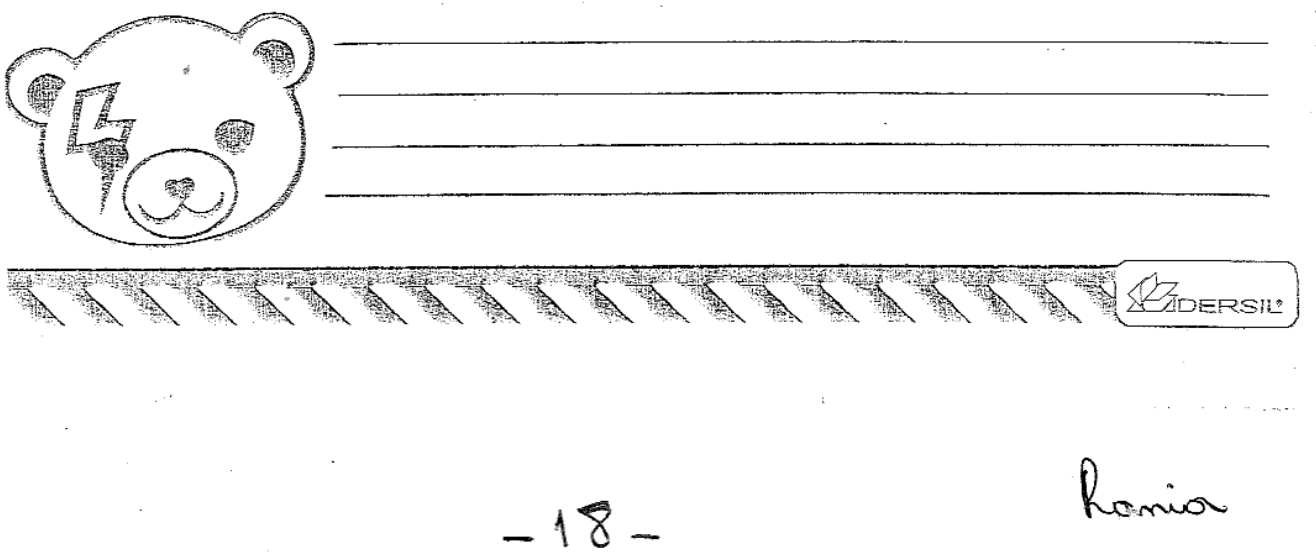

Ramia 
19. ponsabilidade jureni.

04

Al gravidez na adolercência é um tênomeno que

ocorre em muitam familiar com uma frequência - una maior do que nam décadas anteriorem: Erote fato tem atribuido múltiplam caumare consequenciam podendo rer explicado de diserraim 09 maneiram fpemar de ocorrer principalmente" ém pepulacao de baixa renda, adolersenter de "clármem 1 pociaim pribilegiadar também tazem parte dar 12 entratimticar de lowenn que engravidam faf 13 prococemente. Algung culoam a falta de in14 formaccia mam onumero de iniciatigam para 15 promer a educaçao mexual monistra que ersta 16 ná é a unica cauma dese-me lesar em conta 17 a rexualidade prococe dom josens, mam princi13 palmente a irremponmalidade

19 Há também on amon de abandono, deum 20 dom losenm; da rempon mabilidade paterna, ha mai 21 orica dom camors a maje é chondonada com a crian22. ca. Também conntam o abor to e o abandono do 23 behê pela tamilia

24 Come on frotos monotram, näo basta copenas enni 25 nar om jogenis a fazer em bexa com sequrança 26 caletá-lom mobre on rimcom Enecemario "que om 27 adolemcenter tenham maturidade, que cimsumam - 28 a remoonmabilidade oor neum ators. 29

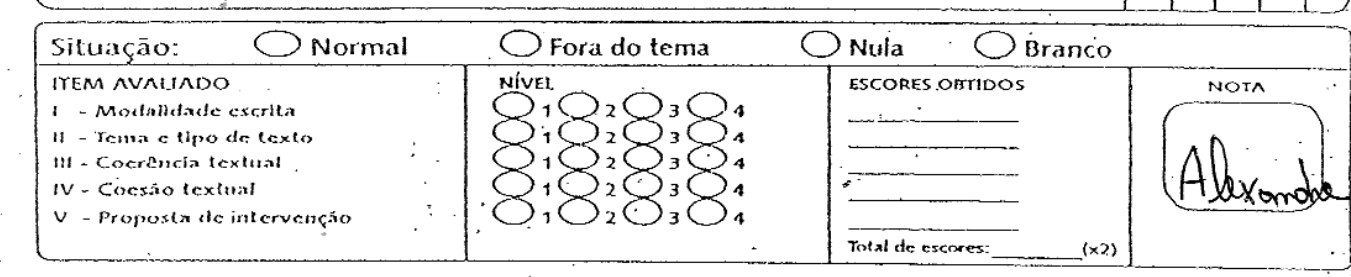


20.

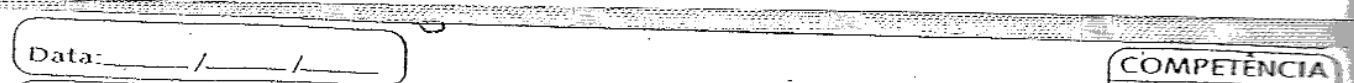

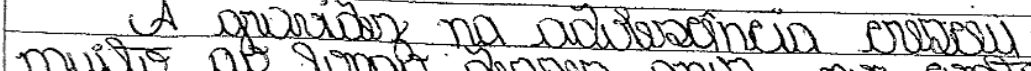

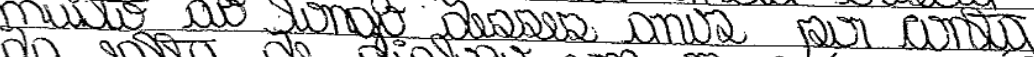

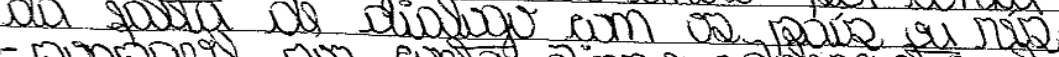

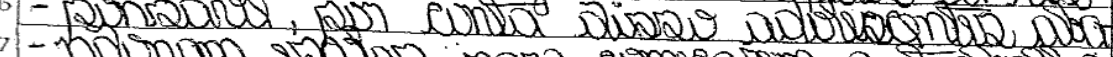

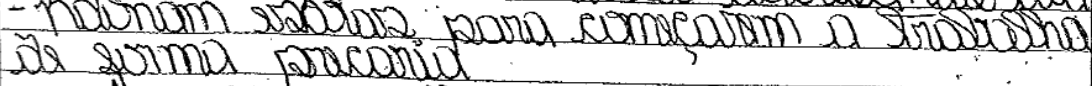

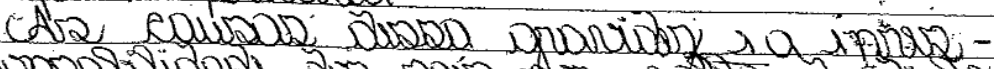

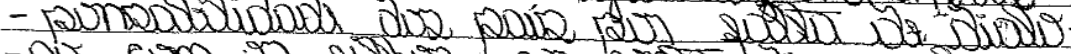

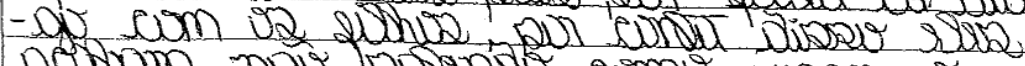

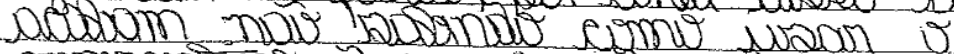

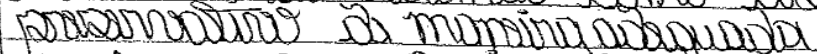

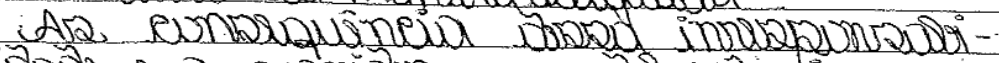

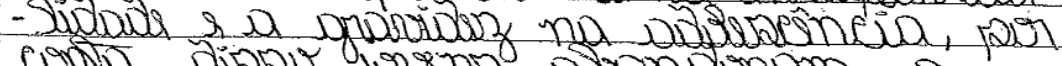

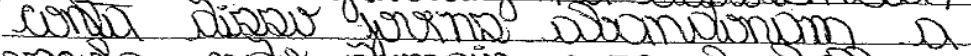

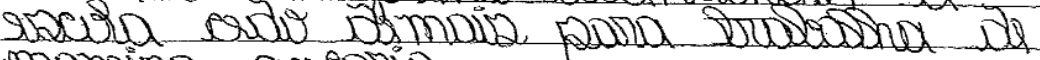

maneira preconia

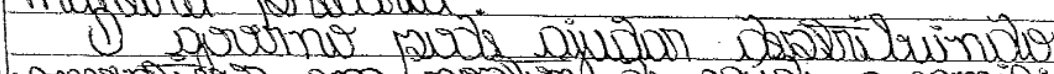

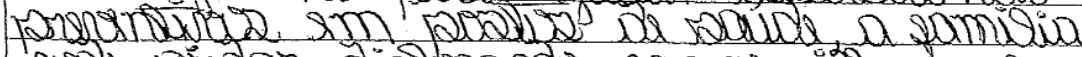

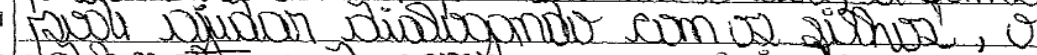

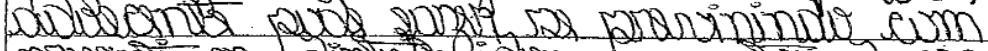

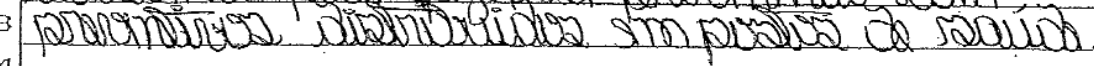
24

26

28

30

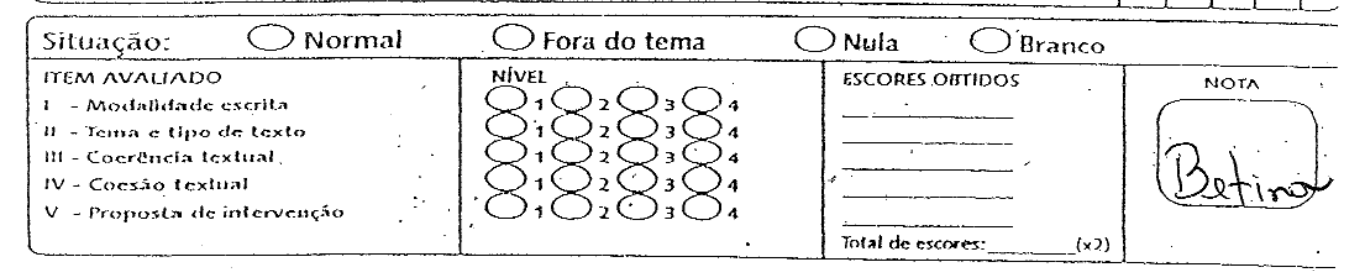

$-20-$ 
21.

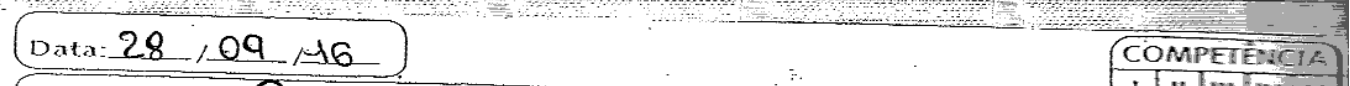

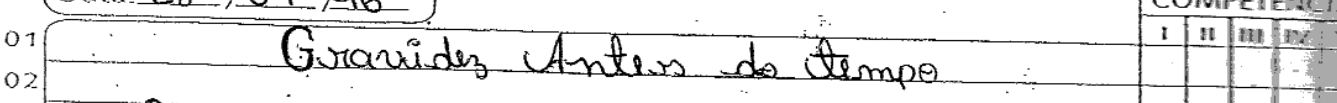

4

Quande usi está na fass do Adalencincia

lude is um pouce conhusse. Is Adxlessentes, enno

diz epraprio noms, nâa saar adultos is nam

7 mas erianco 2 diante desta realidade a framiziscó.

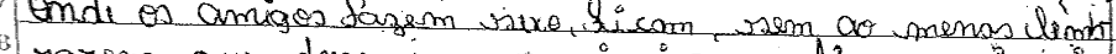

Os Menine achom que os meninas que devioni

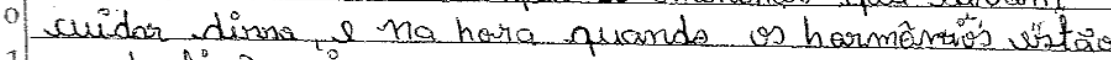

"sm sbulicasa, ai meame que ssi "siaquecem" s move miaw

12 depsios vac sas lebror dr besterira qus fizerion.

A graxides na Adaliscencia tem au te comsiop

tanito pari

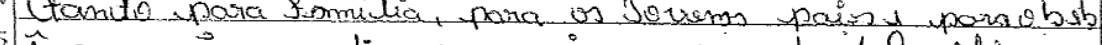

i que naio psdirs para vir as mundo A fomilia

16 Muriter das vezes nöe tem comalicaiss de suxuten

tor mais um membro is pais tem que para de es

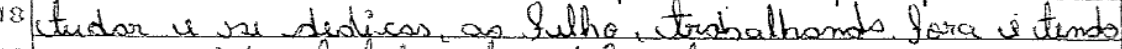

19 uma vida tostalmente difurente ias crianeos cres.

$20 \mathrm{sem}$. par vezer, sem io pai Há veseç̃es, paren iäe

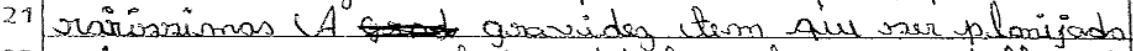

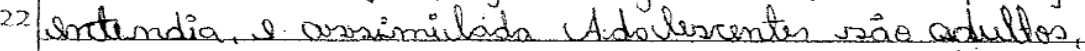

23 mos rabem discermir $\theta$ ais iham ous mol para a

2.4 vida deles pena ques os harmanios mäo deixar raci-

25 ocinar no ixato mamento da vesetha Mos rim dianules

26 aprendem is enquanto iss so, inncentes säe po.

27 satos no Mendo.

283

29

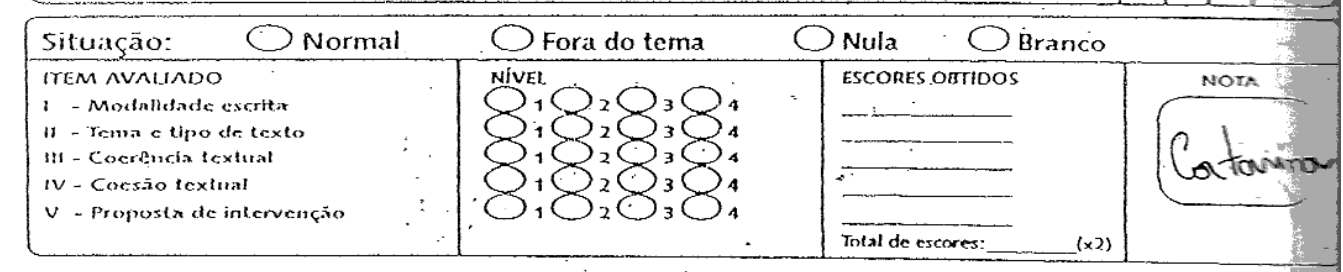

$-21-$ 
22.

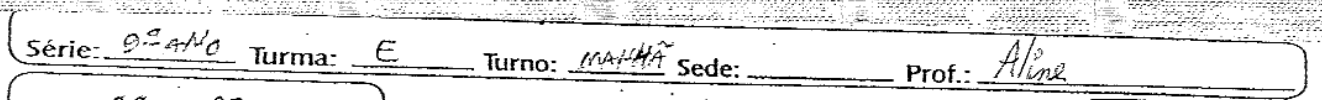
Data: 28 1.09 120-15

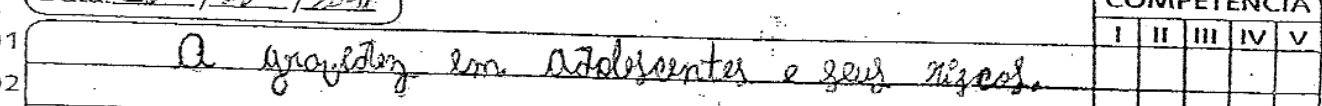

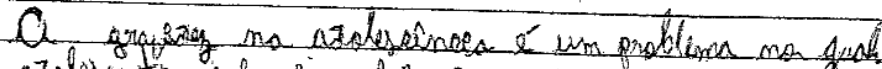

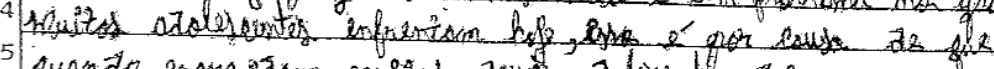

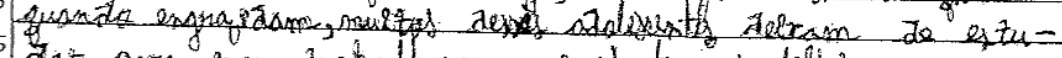

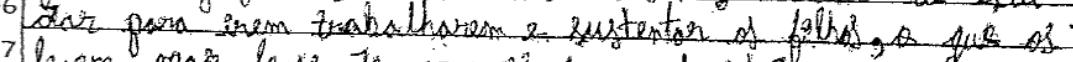

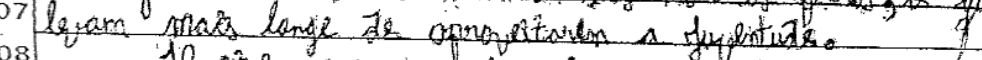

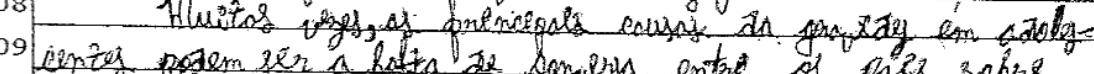

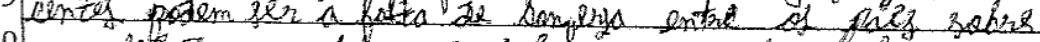

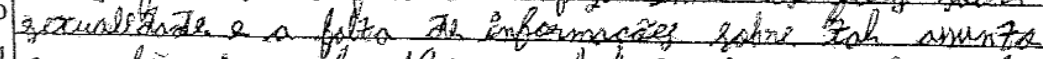

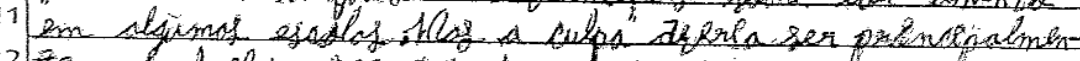

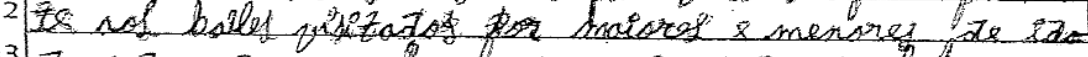

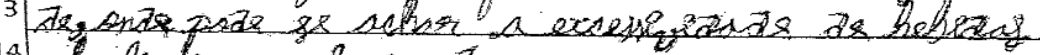

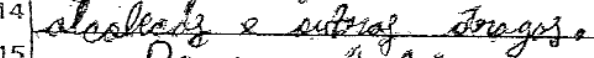

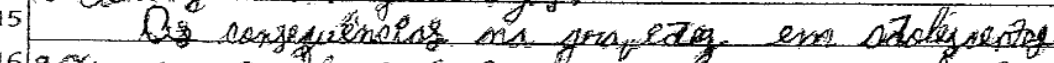

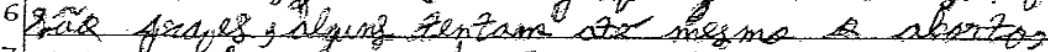

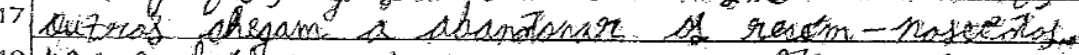

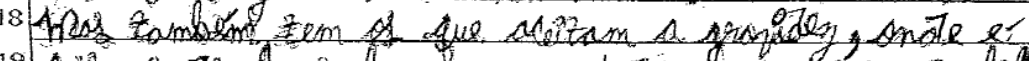

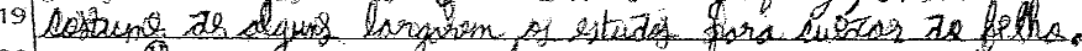

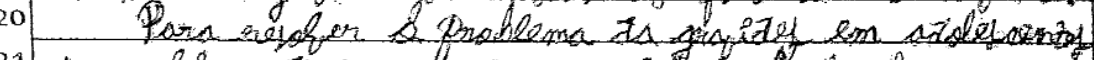

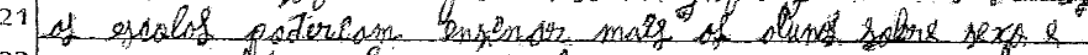

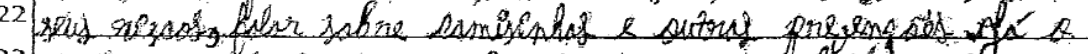

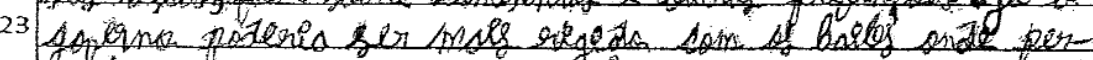

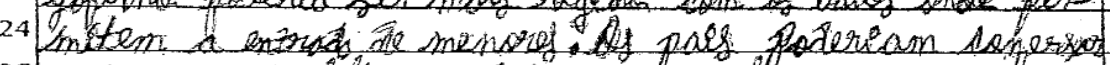

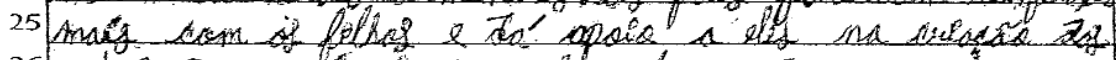

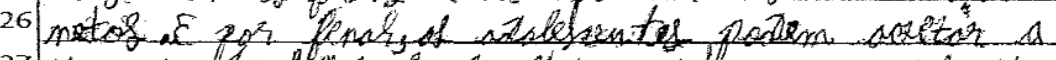

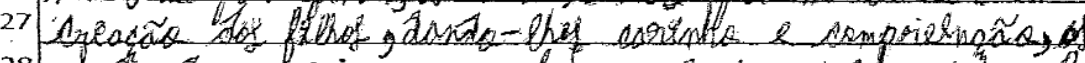

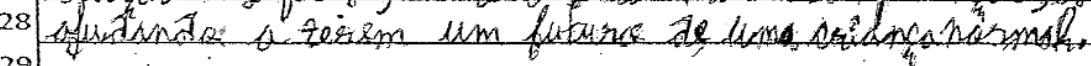
30

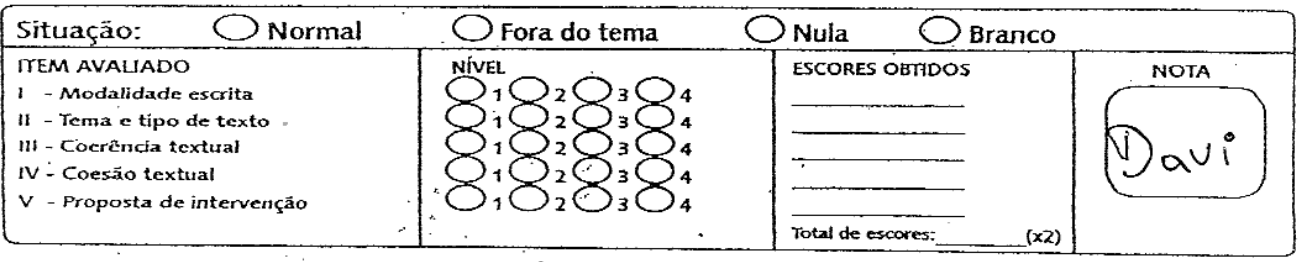


23.

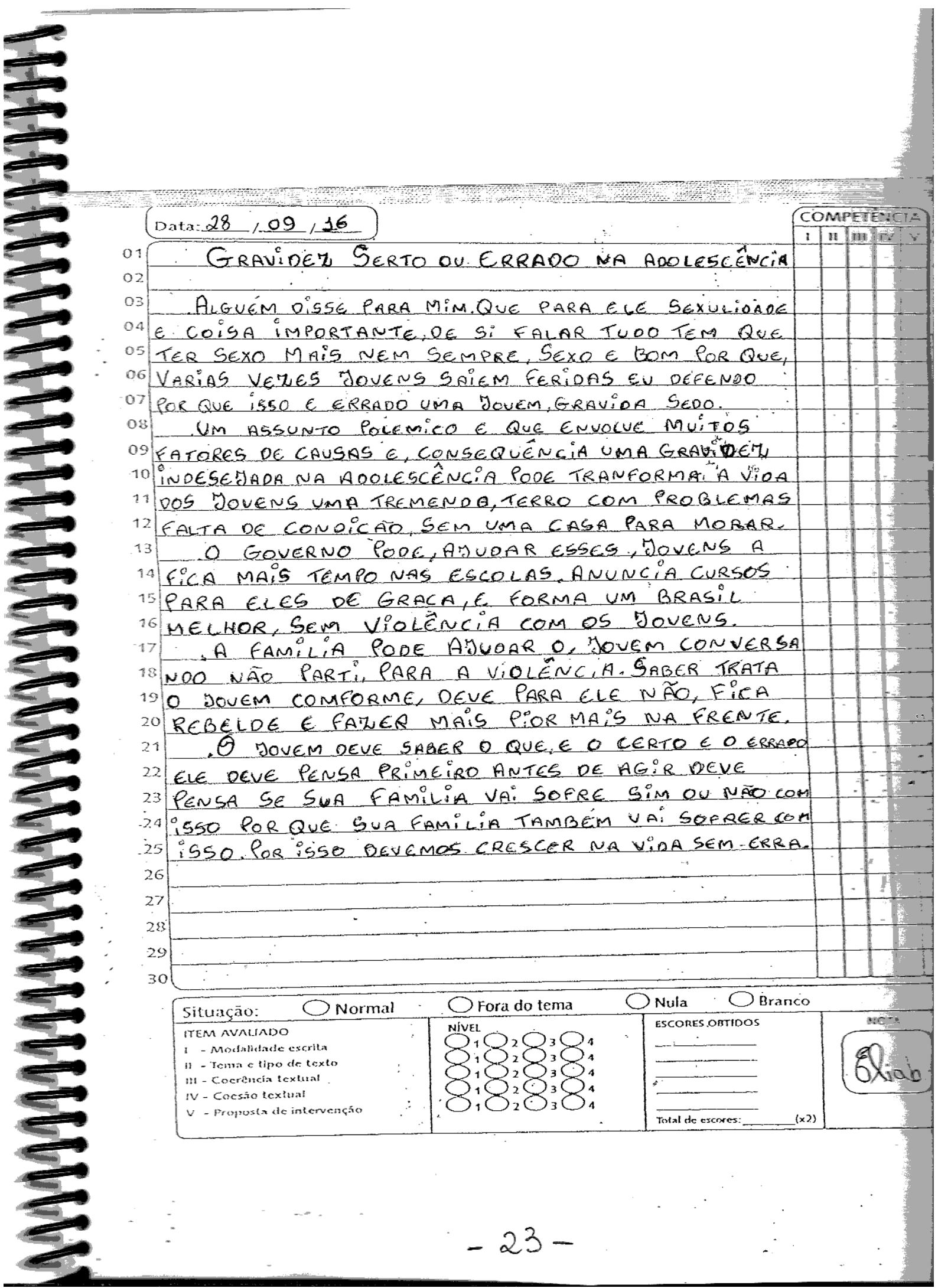


24.

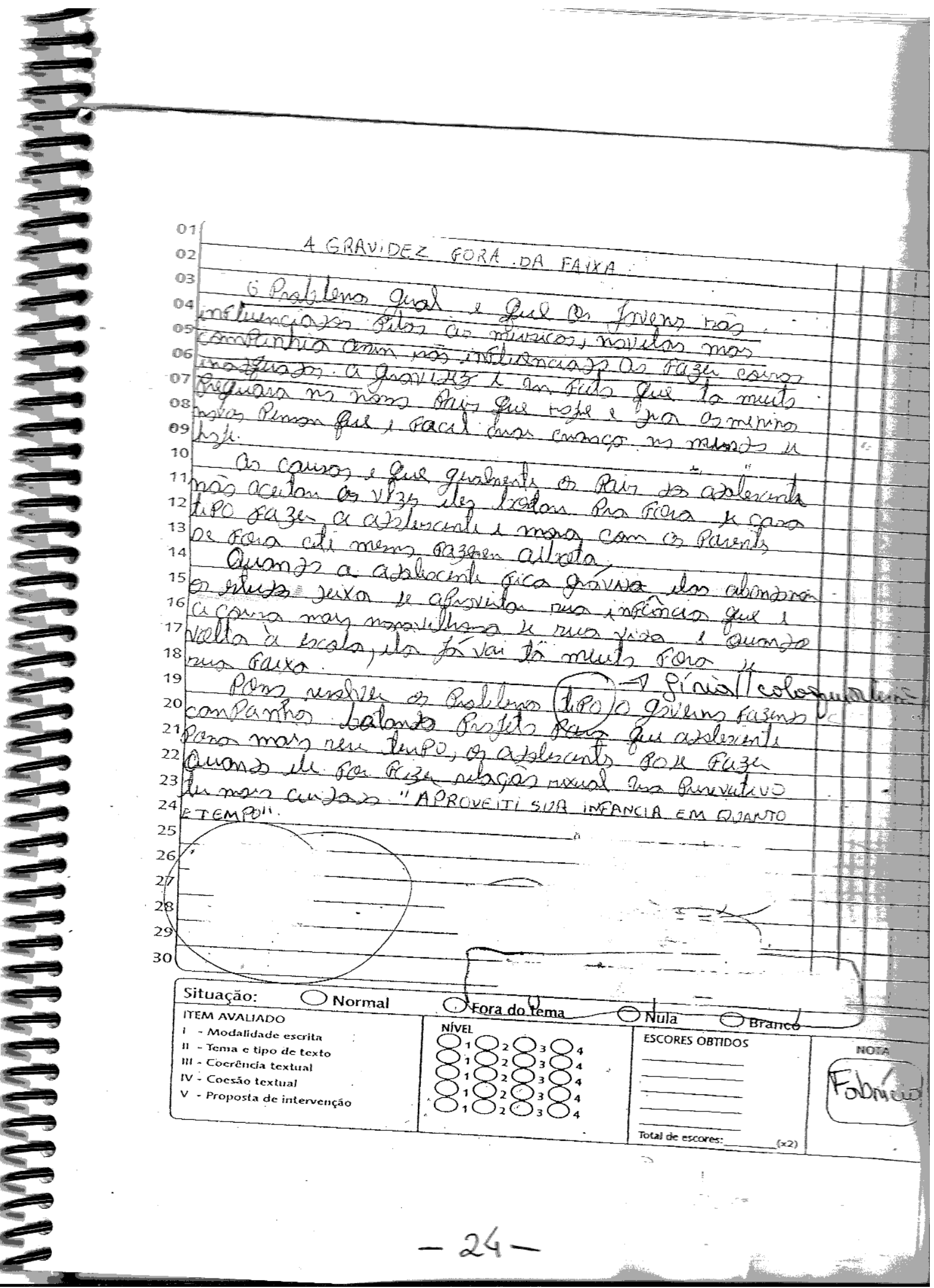


25.

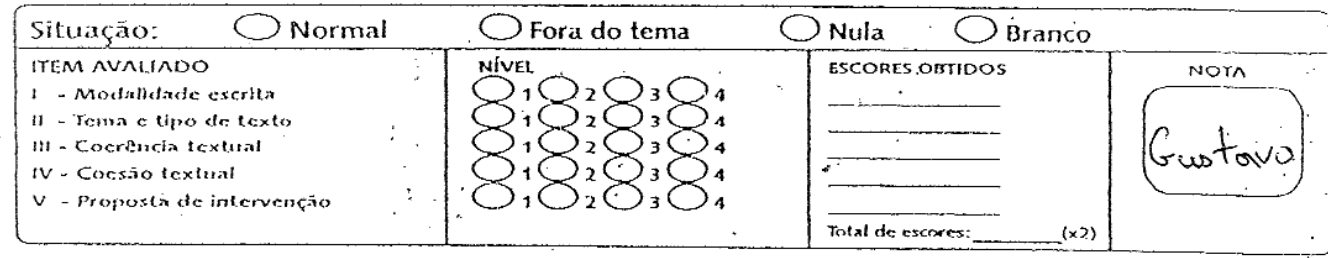


26.

Data:28109,16 (A GRAVIDEZ \begin{tabular}{ll}
\hline COMPETENCIA \\
\hline $1.11-11$ IV
\end{tabular}

muito complicada adoleceneia l' ma eirisai fode ser expuls par causa uque a adulecente cona o porque o erpo nắ pona o pocesse pina a na lata preporade - pantre i ara nora do pato.

para uma adulecinter lom a muito prigosio 33 onos porque o cor la idade Bascaida em sta preparado pora dessa menima niäo e wha que processe de porte rusim as uezes qu as eonsequéneiss émuito dopieir que a moca a nem eonhece orapas des meninos el plerigangatida a mairia com o pai da eriereadas a re ajunta

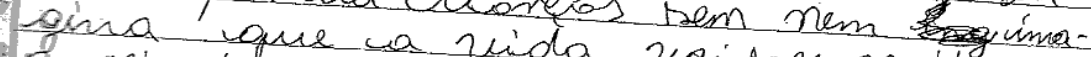
Compliazota vida vai ter muitis aponha tiodos wa dias das Uezes a moca sozinha, emoventio difica en eosa se em es amiges. rapaz fica eurtion. edopor mais grativid prede fozes í essas adoleneenter wo pais encoma scupa eprovita a propria cadictecedo

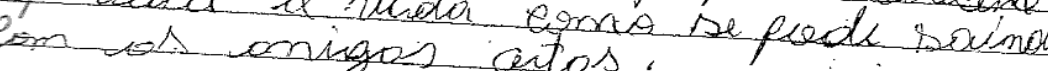

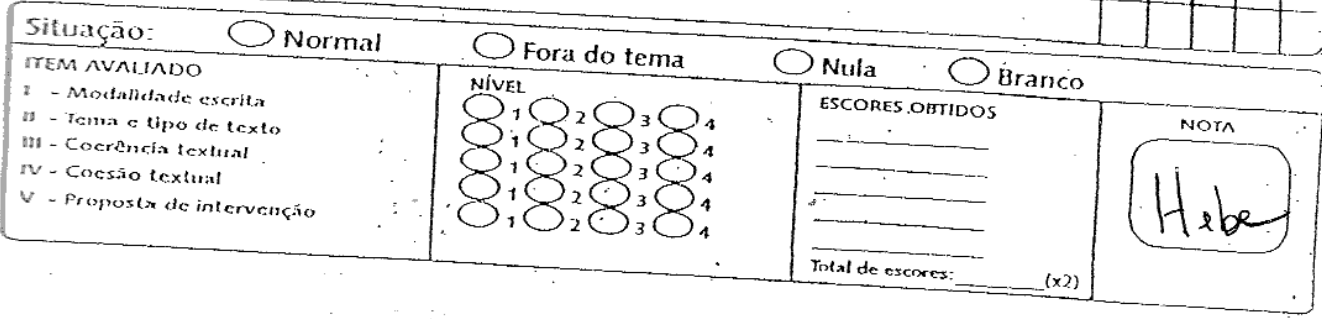


27.

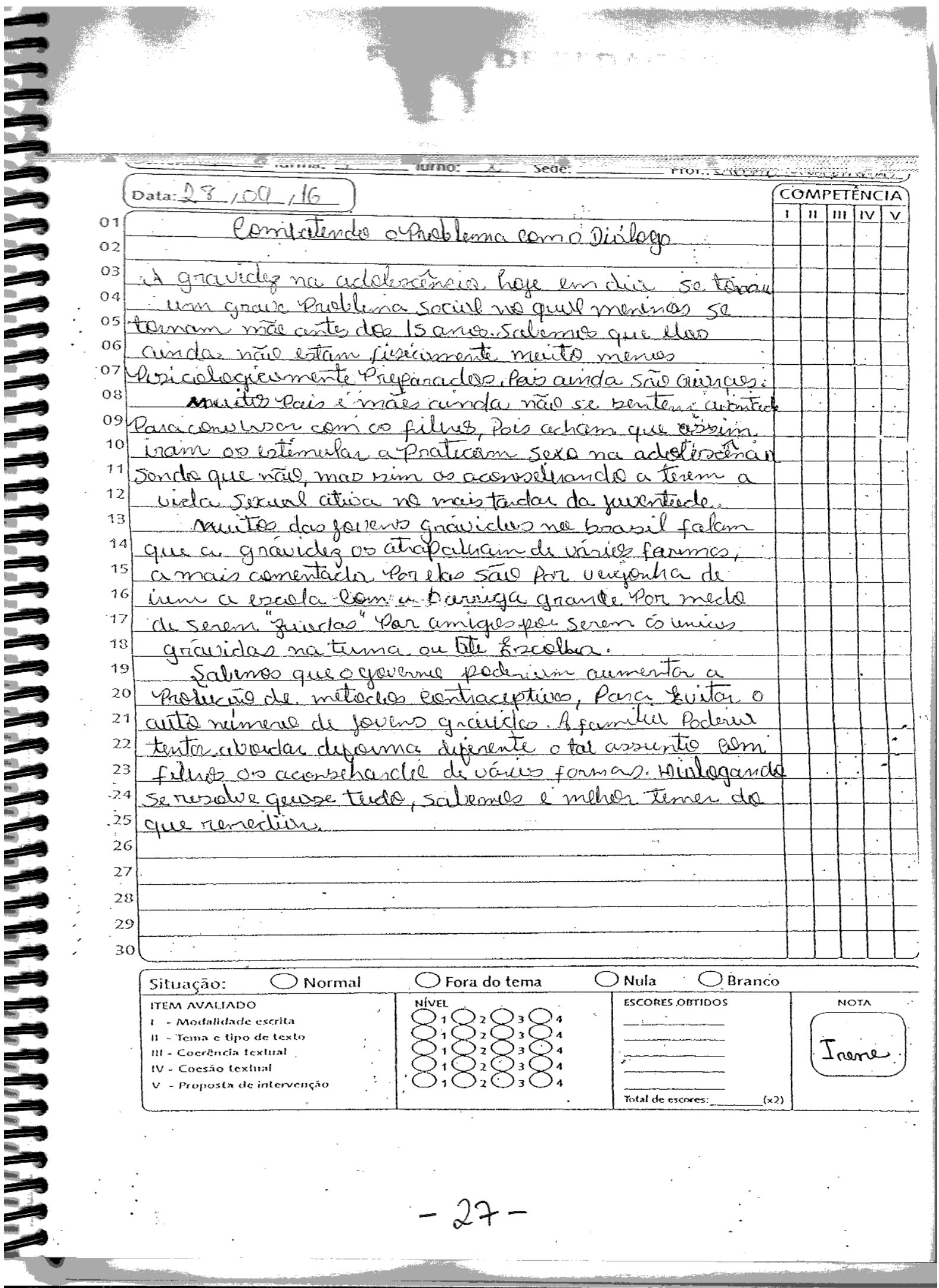


28.

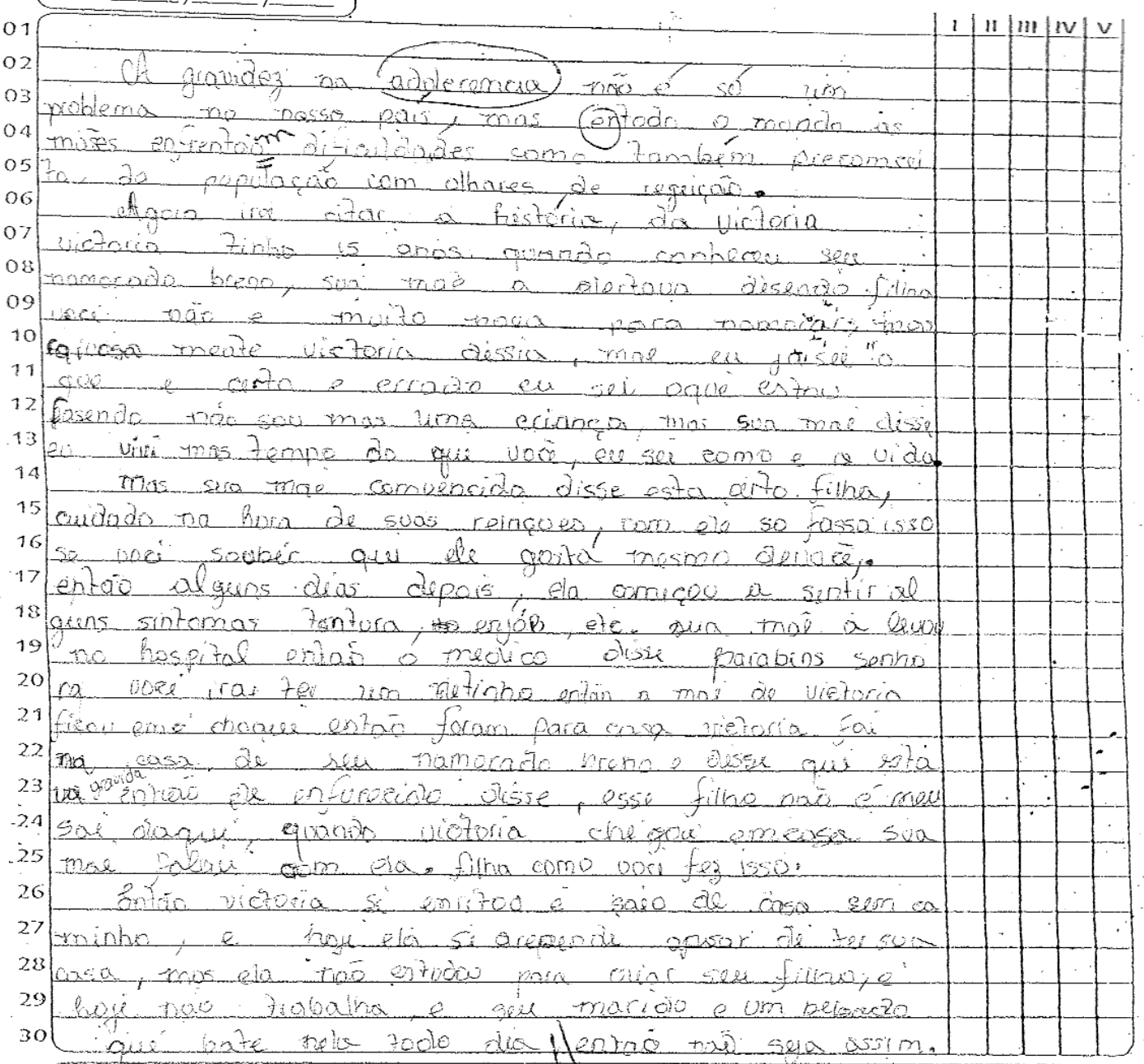

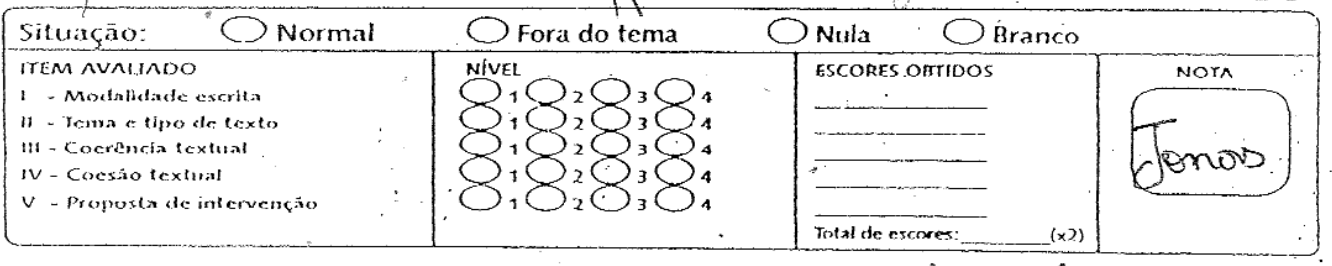


29.

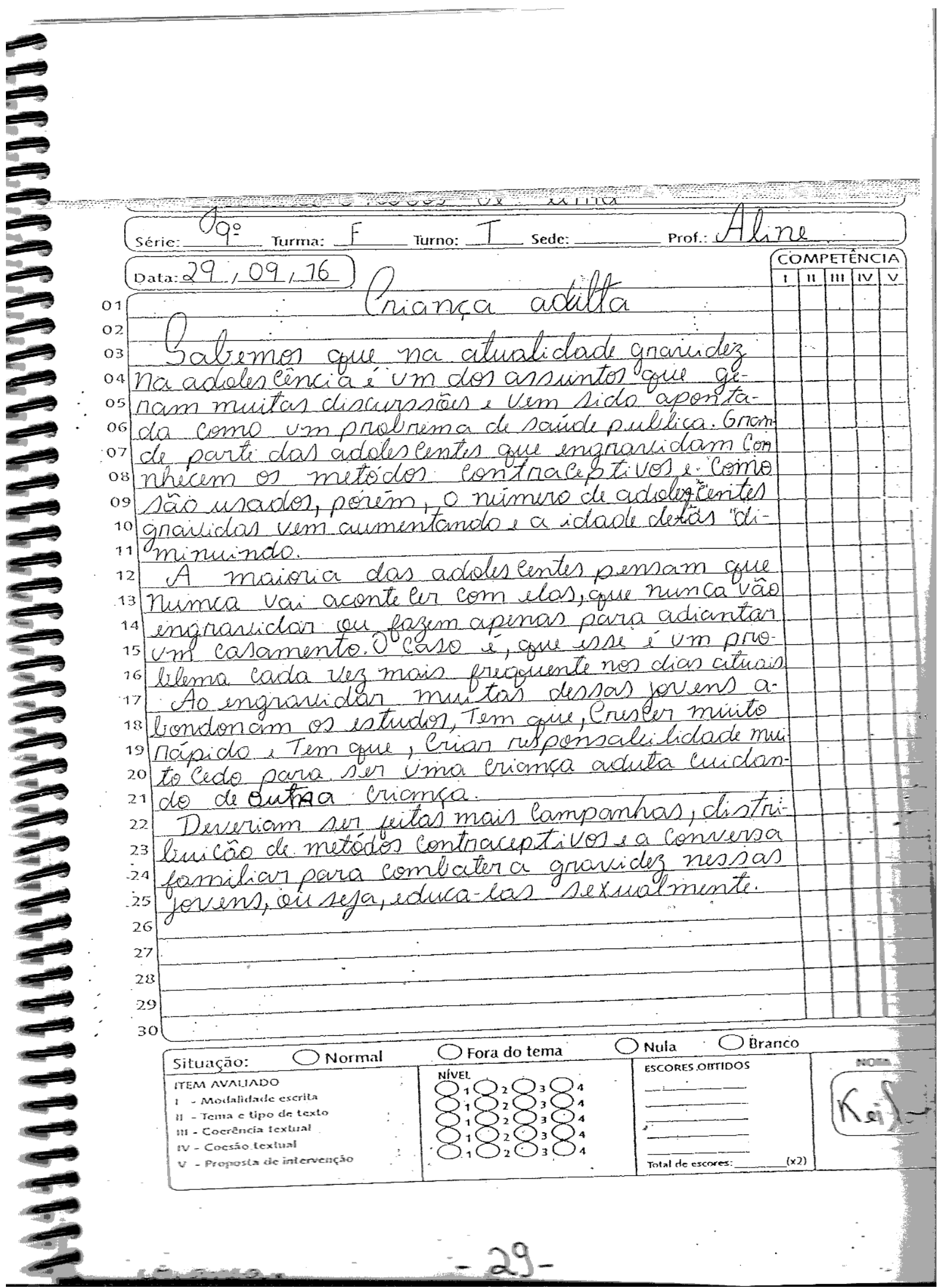


30.

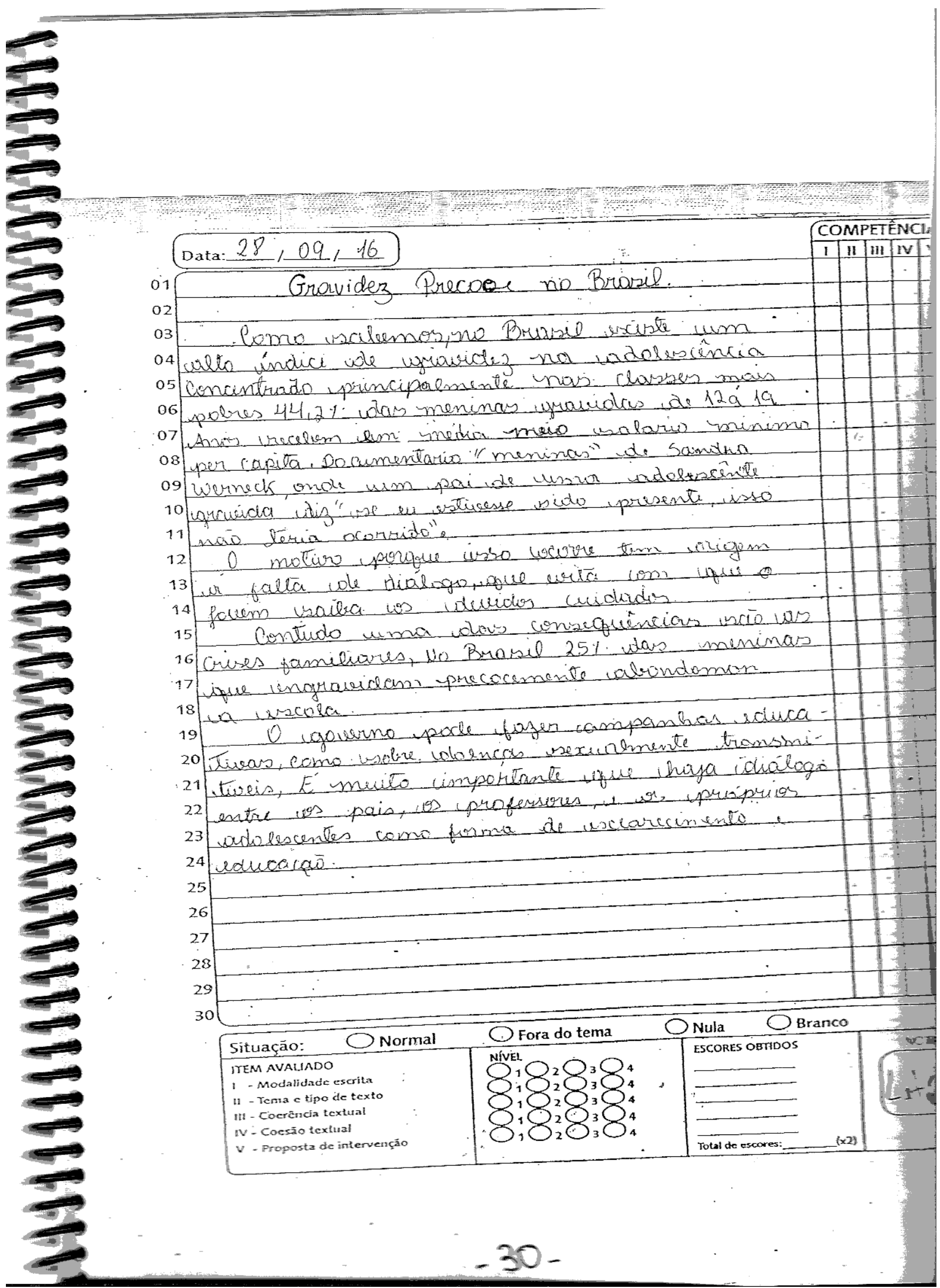


31.

(Data: 28,09 , I I )

COMPETENCIA

Qr iniscor do gravidez

O

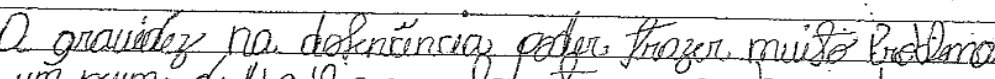
para un joum de 4 a 19 eque elas tim na roberai de puzer

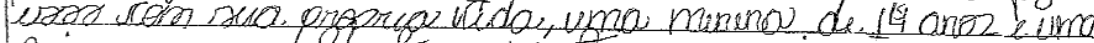

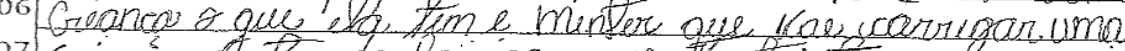

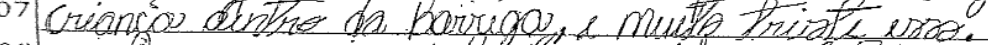

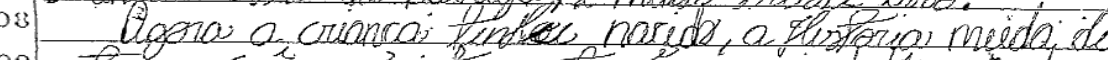

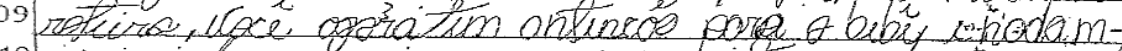

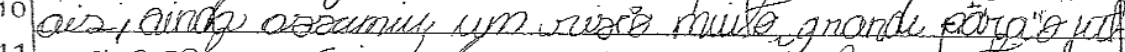

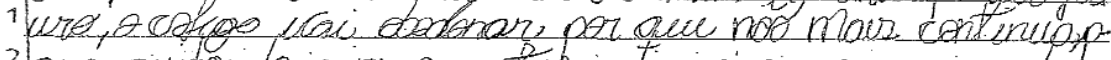

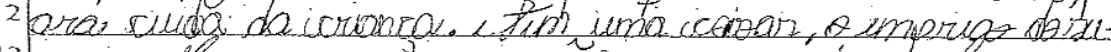

13 es zonfle per rouvo que nö jemprumir.

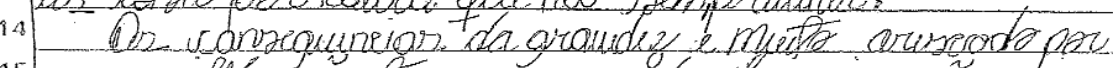

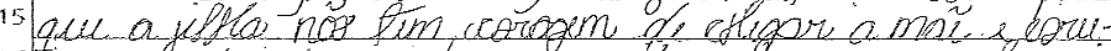

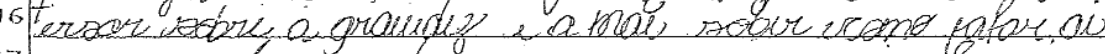

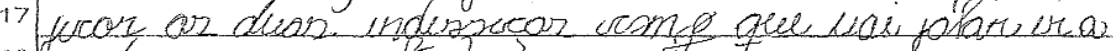

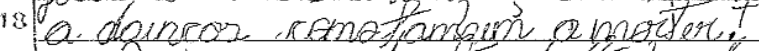

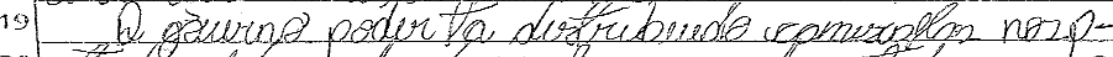

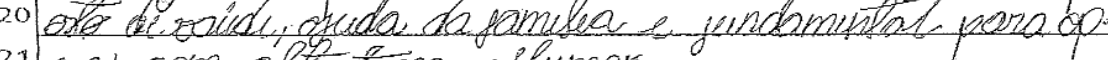

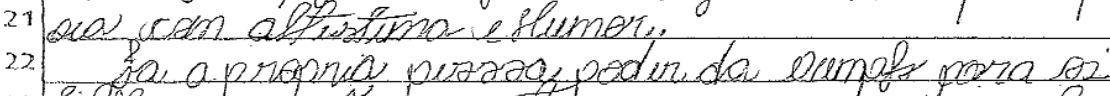

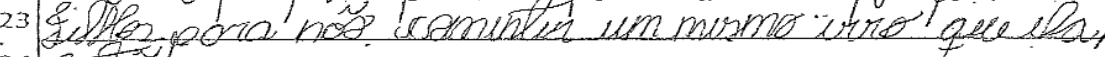

24 9nosizer jerisenor

6

27

23

3

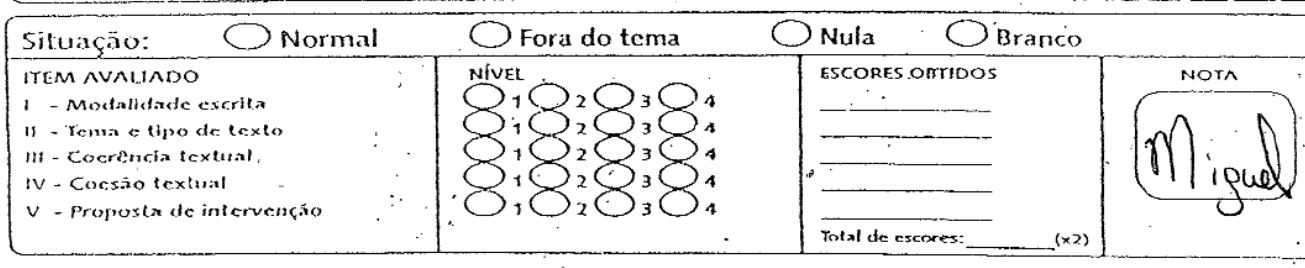

$-31-$ 
32.

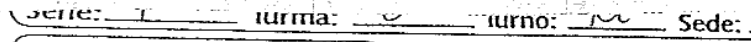

Prof.: $A$ ree nix

Data: 28109116

01

Polaberintia temmindo

03

04

6

Q Prable ma 2 t

8

rawi-ares procace

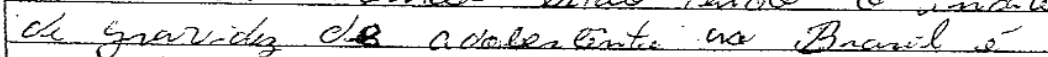

06 convita graunde.

07 a A lnavion dar Cansa a hravionia das

08 Vezer scio as mis mai Falta cle chalogra

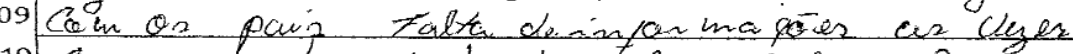

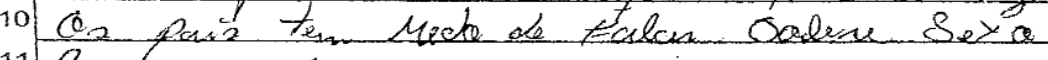

11 Cam or Eihon

12 Cis cans

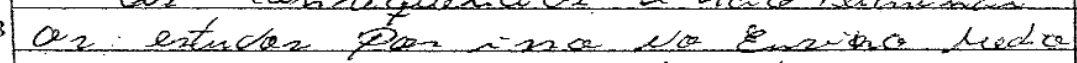

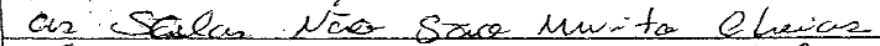

15 Cana ve varima Fundancental tombien

16 exizte puigan vas Fanilias

77.

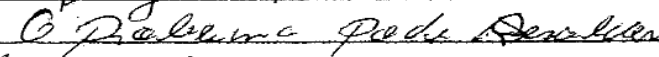

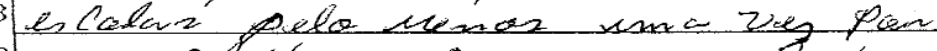

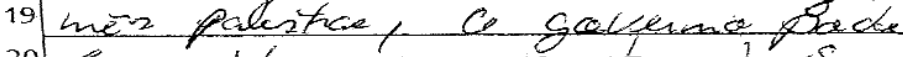

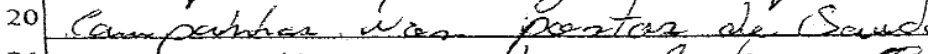

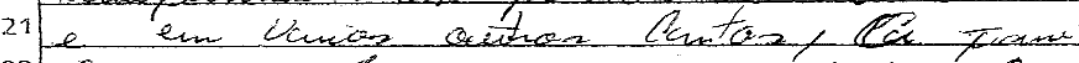

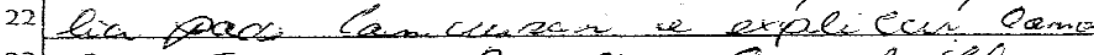

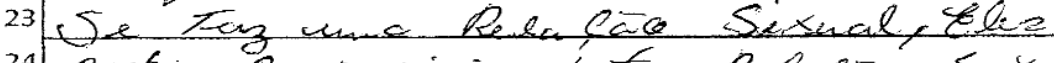

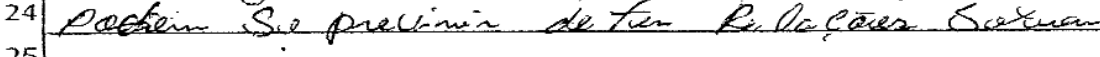

25

26

27

28

29

30

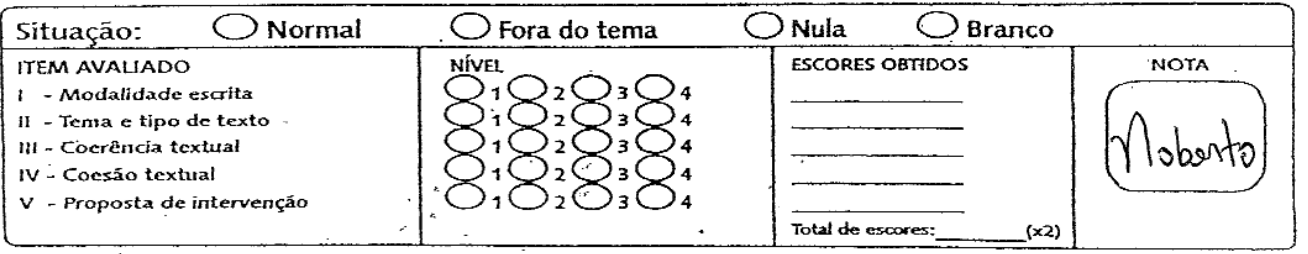

$-32-$ 
33.

(Data: $28,09,16$ )

01 un fator preucupante

02

O Brabil zem zm sério fazor que prevcupa muizo que

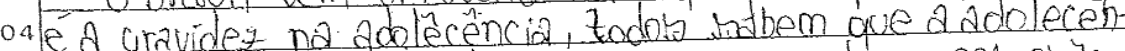

o5 cia e uma tabe onde elaro ejotam coma cabeca nobs ebtu06 dos aluumab ainda brincanm de bonecars, penizam na profi-

07 yatad oue iram exerce no forturo.

08 ts adolecencenteb nà fem uma ejotrutura física e

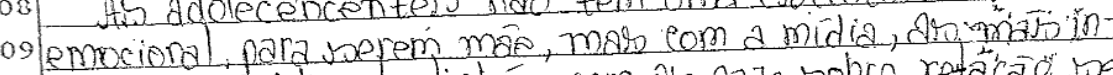

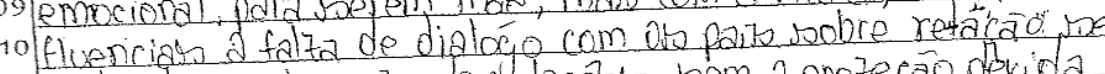

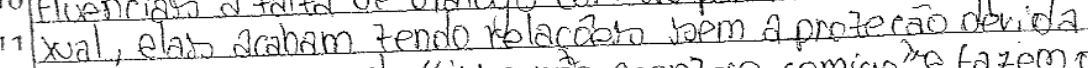

12 com o pentamonizo de "ibbo nào aconzere comigo "te tazeno

1314 to. De acorde como documon zario "meninas", de sanolra wert 15 neck a falta de azencào com a adolerēnze tez comoue ela

16 engraudasde cedo e bé lamenzou paque da iria para de es-

12 D gocerno nodoria fajer eamanhas conzra a gravidez pr

19 covere tazendo a núneios de feleviboets e radiat dando

20 mais in formernaz e distribuindo anzicopcio naito e proze-

21 (ิ)

2.2

23

$-24$

25

27

283

29

30

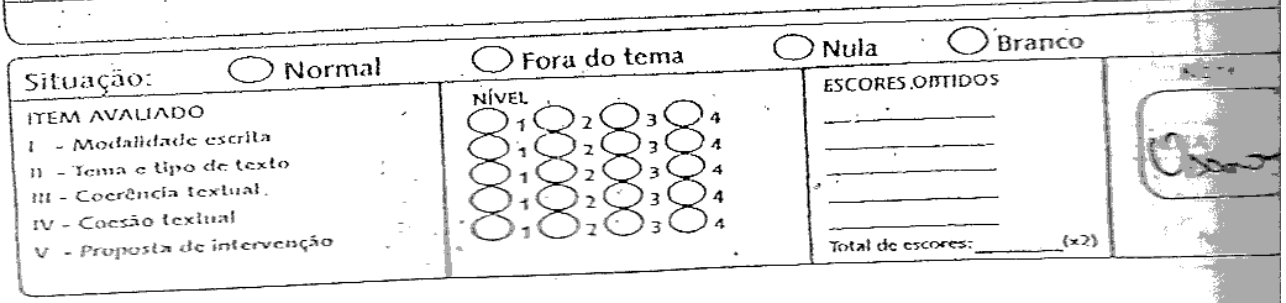


34.

Data: $28,109,16$ COMPETENCIA

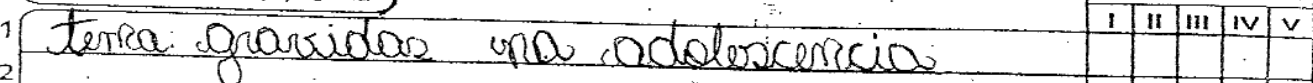
- Co adolecentes de hofe em dio naótem

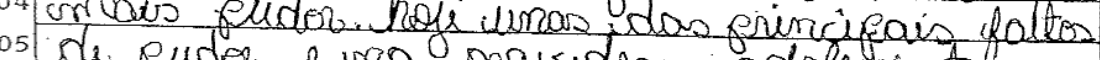
5 de puder e vra onarudezz adolescentes

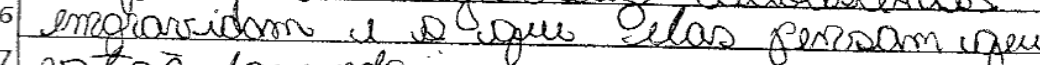
7 estioa fazerndo.

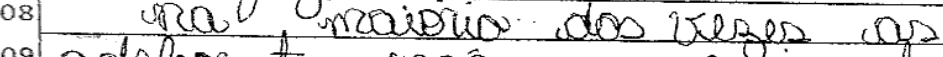

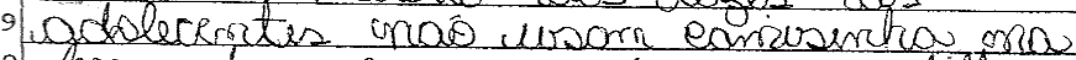
hora do usexo i cusoin arrom fillios premotures lara qesquiso feeta pelo IBCSE urrestra ques $90 \%$ dos uncencinos

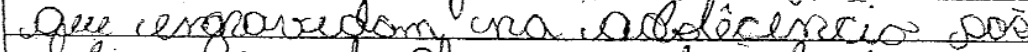
alires ca de lasse viedio liaira 5 Defois da cadolecerrtu engravedo 16 rem as torrsequereos u quasis sote?

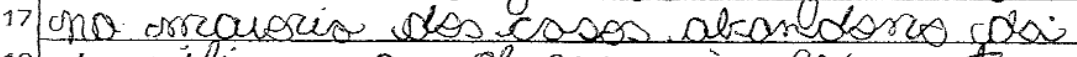
18 forrition a ia cleprespoò pes porte

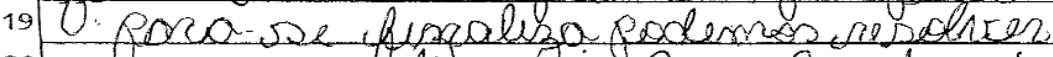

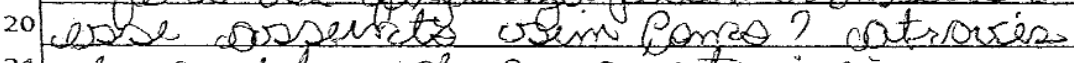

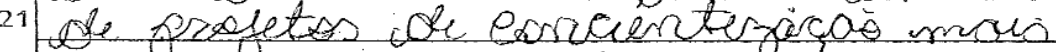

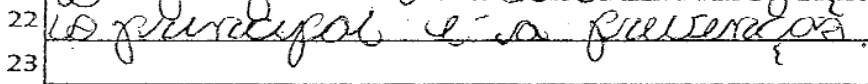

24

25

26 28 29 30

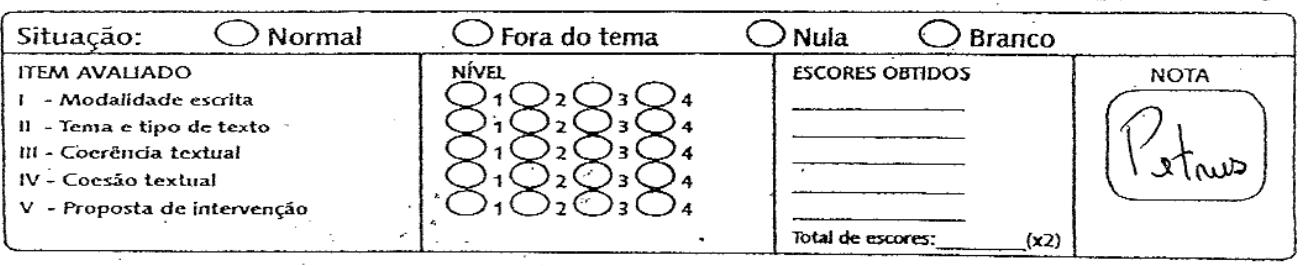


35.

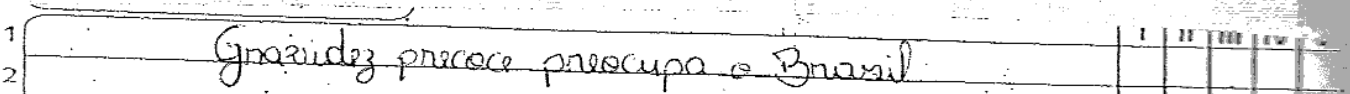

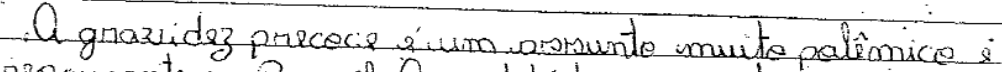

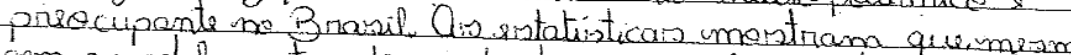

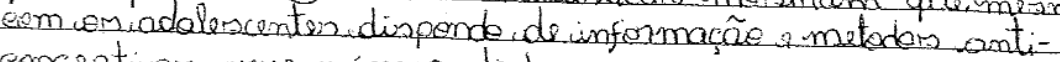

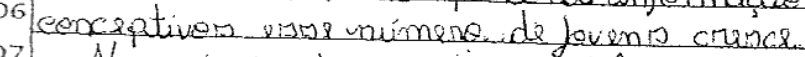

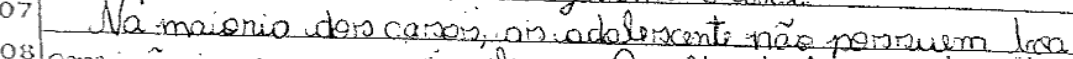

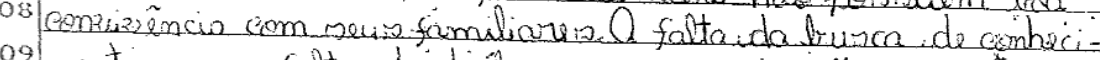

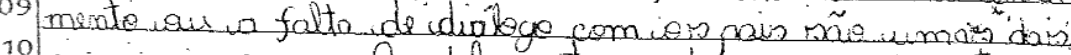

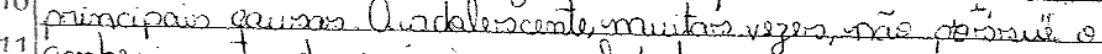

11 Conhr cimento da preipria rexualidade

12 Dr acarde com a Rorely Sowño,

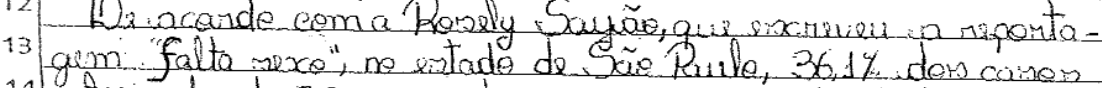

14 natificado de DST concentram-rse na faira de idade 13 \& 24

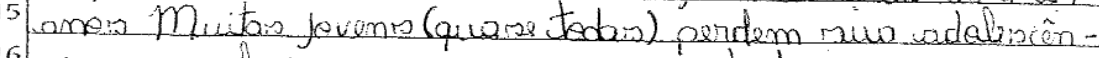

16 eia sem alguins carsos param ien sistudors para zs eoncen-

17 tror no suo misponralilidad.

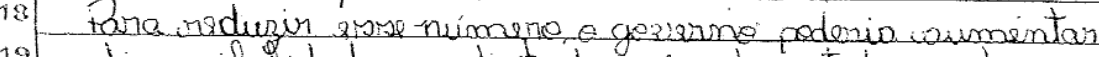

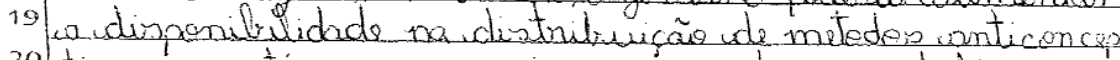

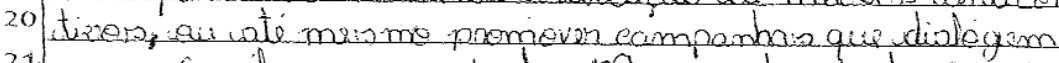

21.

22.00

u familu para afudar. Mas nada afudará mais do

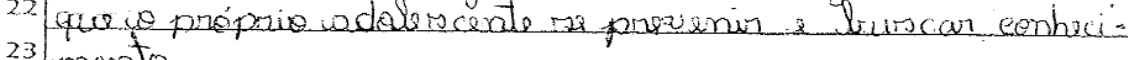

23 minto

-2.4
.25

26

27.

28

29

30

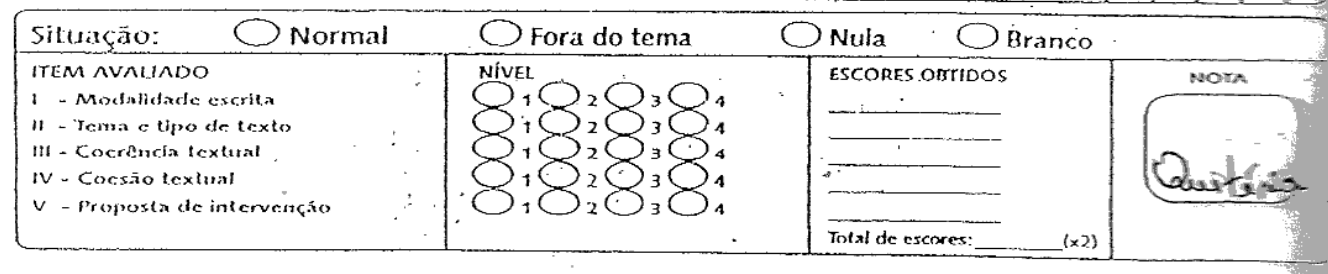

$-35-$ 
36.

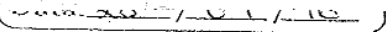

01

12.

03

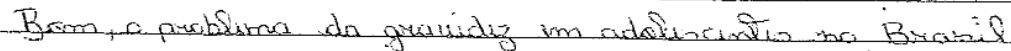

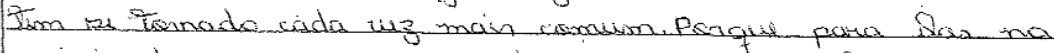

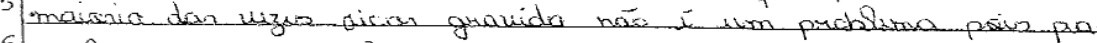

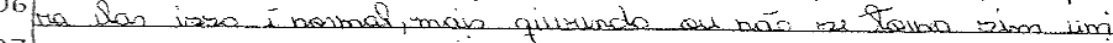

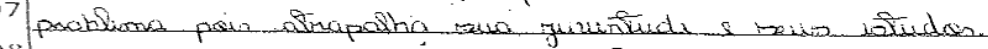

08

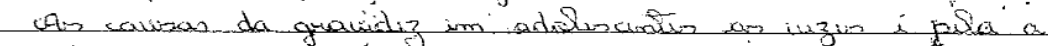

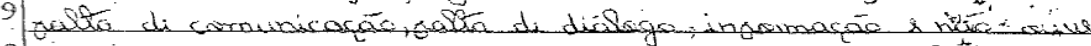

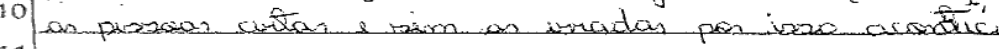

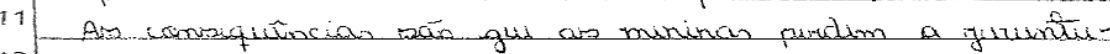

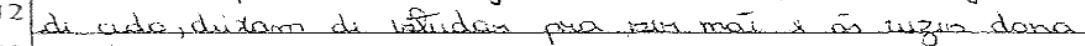

13 de conza.

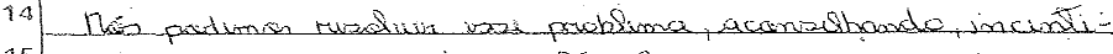

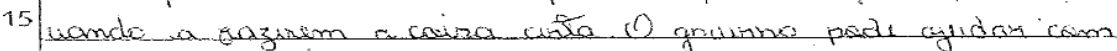

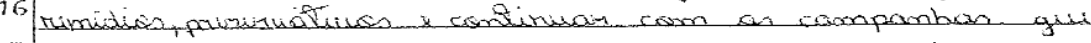

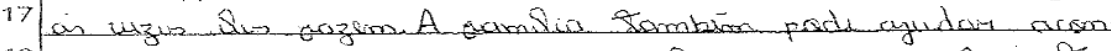

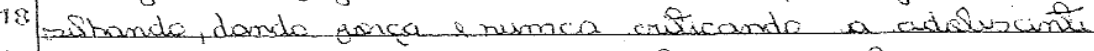

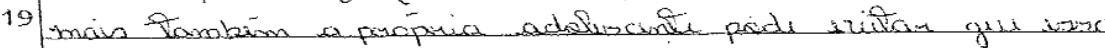

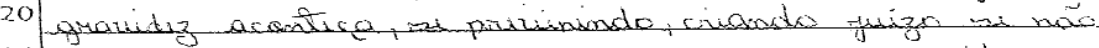

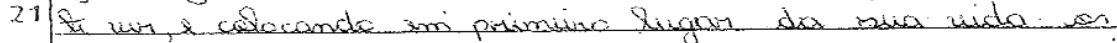

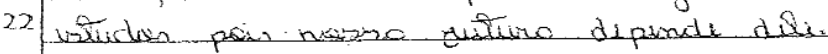

23

.24

25

26

27

28

29

30

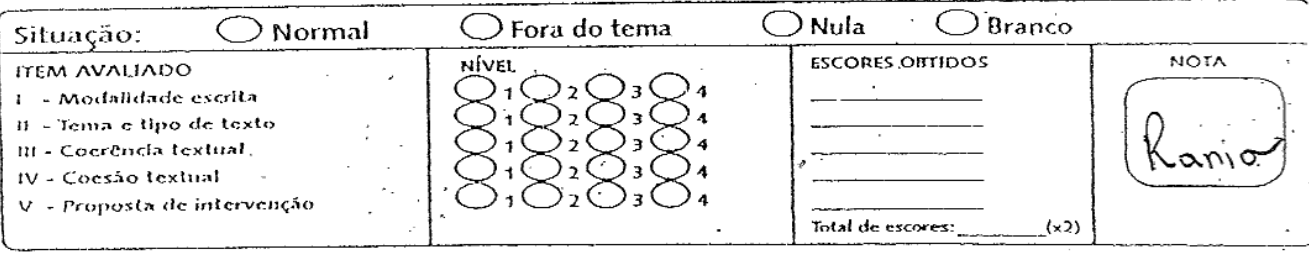

$-36-$ 